\title{
"Procesos políticamente expuestos": La falta de garantías judiciales en el juzgamiento a figuras políticas y el descreimiento social en los tribunales
}

\section{'Politically Exposed Legal Proceedings': The Lack of Judicial Guarantees in the Prosecution of Political Figures and Social Disbelief in Courts}

Ignacio A. BOULin Victoria ${ }^{1}$ y María Fabiola CAntú ${ }^{2}$

Resumen: Este trabajo analiza distintos aspectos vinculados al rol de los tribunales en el juzgamiento de figuras políticas de altos rangos, en lo que se denominarán procesos políticamente expuestos. Se verá que para que las decisiones judiciales que se adopten tengan legitimidad suficiente para ser aceptadas por los disconformes con el resultado es crucial contar con procesos judiciales transparentes y respetuosos de las garantías del debido proceso. Se tratará el deber de imparcialidad de los jueces, la garantía del juez natural y la cuestión de la igualdad en el proceso. También se expondrán cuestiones vinculadas a la confidencialidad en la relación abogado y cliente en estos casos, así como a las garantías que deben respetarse para mantener indemne el contenido esencial del derecho a la privacidad.

\footnotetext{
1 Abogado por la Universidad de Mendoza (Argentina), Máster en Derecho Administrativo por la Universidad Austral (Argentina), LL.M Harvard Law School, Profesor en la Universidad Nacional de Cuyo y la Universidad Austral.

${ }^{2}$ Abogada por la Universidad Nacional de Cuyo (Argentina), Diplomada en Derechos Humanos por la Universidad Austral (Argentina), Diplomada en Defensa Internacional de los Derechos Humanos por la Escuela de Práctica Jurídica de la Universidad de Zaragoza (España).
} 
Estos aspectos son de cabal relevancia pues la politización de los tribunales suele evidenciarse al violar los deberes funcionales. Se procurará, a la vez, mostrar casos de la realidad latinoamericana reciente para ejemplificar los puntos que se hacen.

Palabras clave: Procesos políticamente expuestos, garantías judiciales, descrédito social, confidencialidad, escuchas telefónicas.

Abstract: This paper analyzes different aspects related to the role of the courts in the trial of high-ranking political figures, in what will be called politically exposed processes. It will be shown that in order for judicial decisions to have sufficient legitimacy to be accepted by those who disagree with the outcome, it is crucial to have transparent judicial processes that respect the guarantees of due process. The duty of impartiality of judges, the guarantee of the natural judge and the issue of equality in the process will be discussed. Issues related to confidentiality in the attorney-client relationship in these cases will also be discussed, as well as the guarantees that must be respected in order to maintain the essential content of the right to privacy unscathed. These aspects are of utmost relevance since the politicization of the courts is often evidenced by the violation of functional duties. At the same time, an attempt will be made to show cases of the recent Latin American reality to exemplify the points made.

Key words: Politically exposed proceedings, judicial guarantees, social discredit, confidentiality, wiretapping.

Recibido: 17.3.2021Ａceptado: 15.6.2021 


\section{Introducción}

Expresidentes de Colombia, Argentina, Perú, Brasil y Paraguay han sido sometidos - o lo están siendo en este momento - a procesos penales en los que se los acusa por la comisión de distintos delitos ${ }^{3}$. La relevancia política de estas personas hace que estos casos judiciales influyan en el debate público y en el proceso democrático. Son procesos políticamente expuestos ${ }^{4}$.

En relación al debate público, las sociedades se polarizan en torno a la inocencia o culpabilidad de los investigados, muchas veces según la postura política previa. Sin embargo, su destino ante los tribunales no depende (o no debería depender) de las mayorías populares.

En cuanto al proceso democrático, la afectación de los derechos políticos de estas personas genera una interferencia clara. Privar del derecho al voto a una persona es problemático, pero tiene una implicancia individual. Limitar judicialmente el derecho a presentarse a elecciones a quien podría ser candidato a presidente con altas posibilidades de victoria pone presión a todo el sistema democrático.

\section{a. Jueces y política, legitimidad y descrédito}

Recientes casos muestran que los jueces pueden influir directamente sobre las elecciones, impidiendo a candidatos presentarse $^{5}$. Decisiones que deberían tomarse por mayoría democrática pueden ser adoptadas por tribunales sobre los que se ciernen sospechas.

\footnotetext{
${ }^{3}$ Entre otros, los ex presidentes Fernando Lugo, de Paraguay, Lula da Silva, de Brasil, Cristina Fernández de Kirchner, Alan García, en Perú, Álvaro Uribe, en Colombia.

${ }^{4} \mathrm{La}$ analogía viene, obviamente, de las personas políticamente expuestas. Estas son aquellas que desempeñan o han desempeñado funciones públicas destacadas.

${ }^{5}$ Los casos de Lula Da Silva y de Evo Morales son ejemplos de lo expuesto, sin entrar a considerar si la decisión es acertada o no.
} 
Esto genera diversos inconvenientes. El primero es que el crecimiento del poder de los jueces en la arena política es paralelo al aumento de su descrédito ante la población. Mientras los tribunales son más sospechados de actuar con motivaciones políticas, la ciudadanía menos confía en el poder judicial y acepta en menor grado sus decisiones. ${ }^{6}$. Por eso los tribunales enfrentan una crisis de legitimidad (Pegoraro, 2018). En el año 2018 un estudio mostró que el $71,6 \%$ de las personas de América Latina no confiaban en el Poder Judicial (Estella de Noriega, 2020).

La legitimidad ${ }^{7}$ es un fenómeno variable que se traduce en una cierta cualidad por la que las decisiones que toman quienes detentan el poder estatal son cumplidas incluso por quienes ven sus intereses dañados por tal decisión. Se refleja, en buena medida, en el asentimiento social al ejercicio de la autoridad (Offe, 2011, 453). Si bien los jueces en la región gozan de legitimidad de origen, pues suelen ser designados conforme a los respectivos procedimientos constitucionales, sólo tendrán legitimidad de ejercicio si las personas entienden que los procesos judiciales son íntegros y que llegan a sus resultados con equidad e imparcialidad (Faulkner and Burnett 2012). De hecho, hay estudios que demuestran que el principal factor que influye en la aceptación voluntaria de la decisión de una autoridad estatal (ya sea un juez o una autoridad administrativa) es la imparcialidad del procedimiento de toma de decisiones (Tyler 2009, 320).

Así, la mera sospecha de la actuación política de los jueces siembra desconfianza en la ciudadanía respecto de su imparcialidad

\footnotetext{
${ }^{6}$ Es interesante la reflexión que realizó el Presidente de la Corte Suprema de Justicia de Argentina, Dr. Carlos Rozenkrantz, en su discurso dando inicio al año del Poder Judicial en 2019: "La crisis de legitimidad, como dije, es en parte una crisis de confianza y la desconfianza creciente de nuestros ciudadanos en el Poder Judicial ha nacido en parte porque existe la sospecha de que servimos a intereses diferentes al derecho. Debemos mostrar que no es el caso. Que no nos servimos del derecho sino que servimos al derecho".

${ }^{7}$ En una clasificación simple, puede distinguirse la legitimidad de origen, referida a las condiciones en la que alguien o algunos acceden al poder, de la legitimidad en el ejercicio, relativa a la forma en la que ese o esos ejercen el poder.
} 
en los procesos, sobre todo en aquellos que tienen por objeto juzgar a figuras políticas. Esto contribuye a deslegitimar el sistema de justicia y sus decisiones. Y mientras menos personas confíen en que sus conflictos pueden ser resueltos en procesos con reglas claras, más acuden a otras soluciones por fuera de la ley.

Para mantener la confianza del público en el sistema judicial, es necesario que los jueces eviten cualquier actividad que pueda tener tintes o implicancias políticas, o que pueda comprometer su independencia o arriesgar su imparcialidad (Naciones Unidas, Relatoría Especial sobre la Independencia de los Magistrados y Abogados, 2020).

\section{b. Las figuras políticas ante los jueces: evitar procesos políticos para revitalizar la confianza de la ciudadanía en los tribunales}

Las figuras políticas, a la vez, no son -ni pueden ser-inmunes al control judicial. El hecho de que representen a sectores mayores o menores del electorado no las pone sobre la ley ${ }^{8}$. Deberían ser juzgadas con vara equivalente un ex presidente y una persona sin poder político: ni con menor ni con mayor severidad.

Ahora bien, si se pretende lograr decisiones judiciales que tengan legitimidad suficiente para ser aceptadas por los disconformes con el resultado (Offe, 2011), es crucial contar con procesos judiciales transparentes y magistrados imparciales a la hora de juzgar a personas vinculadas con la actividad política en altos rangos. Solo así se podrá llegar a sentencias incuestionables, responder a la demanda social de justicia y pacificar una sociedad descreída del sistema judicial (Gómez, 2021).

Sanear la convivencia democrática requiere decisiones judiciales creíbles, emitidas por magistrados respetados. Por eso, los estándares

\footnotetext{
${ }^{8}$ En el famoso caso de las prohibiciones, el juez Edward Coke señaló “Quod Rex non debet esse sub homine, sed sub Deo \& Lege", que significa "El Rey no está bajo ningún hombre, pero sí bajo Dios y la ley". Coke citó en la sentencia al jurista medieval inglés Henry Bracton. La citación del caso en los reportes es 77 E.R. 1342.
} 
internacionales de derechos humanos que deben asegurarse en todo proceso, pero especialmente en este tipo de casos, son de suma trascendencia: no solo por las garantías individuales, sino también por el bien común de tener una justicia reputada en temas de gran interés público (Gómez, 2021).

En este trabajo se analizarán distintos aspectos vinculados al rol de los tribunales que tienen una notoria relevancia en estos procesos políticamente expuestos. En primer lugar, se verá el deber de imparcialidad. En segundo lugar, se estudiará la garantía del juez natural. A continuación, se tratará la cuestión de la igualdad en el proceso. Por último, se expondrán cuestiones vinculadas a la confidencialidad en la relación abogado y cliente en estos casos, así como a las garantías que deben respetarse para mantener indemne el contenido esencial del derecho a la privacidad. Se mostrará que estos aspectos son de cabal relevancia pues la politización de los tribunales suele evidenciarse al violar los deberes funcionales en estas situaciones. Se procurará, a la vez, mostrar casos de la realidad latinoamericana reciente para ejemplificar los puntos que se hacen.

\section{El debido proceso y la imparcialidad de los jueces}

En 1723 el Juez de la Corte Suprema del Reino Unido Fortascue relató en una sentencia haber escuchado que ni siquiera Dios condenó a Adán sin oírlo previamente ${ }^{9}$. Ser juzgado en forma justa es un aspecto fundamental de la convivencia humana que contiene diversos aspectos. Uno básico es que quien juzga debe ser imparcial.

La palabra "imparcial" deriva del latín in-partial, y se refiere a aquel que no es parte en el asunto que debe decidir. La Real Academia Española define a la imparcialidad como la 'falta de designio anticipado o de prevención en favor o en contra de alguien o algo, que

${ }^{9} R$ v Chancellor of the University of Cambridge (Dr Bentley's Case) (1723) 1 Str 557 at 567 [93 ER 698 at 704]. 
permite juzgar o proceder con rectitud'. En este sentido, el carácter de in-partial (que no es parte) del juzgador implica su condición de tercero sin interés personal, político, comercial o de otro tipo en la cuestión a decidir (Isola, 2006).

La imparcialidad supone "la ausencia de designio o de prevención en el juez de poner su función jurisdiccional al servicio del interés particular de una de las partes" (Montero Aroca, 2006, 69). A través de la imparcialidad judicial la ley pueda ser aplicada por magistrados sin inclinaciones personales o prejuicios hacia los individuos que están envueltos en un proceso (Sharman, 1996, 16). En forma analítica se ha descrito que la imparcialidad supone que que el juez (i) no sea parte en el proceso, (ii) que no tenga interés en el proceso o su resultado, y (iii) que actúe únicamente siguiendo a la ley, sin una subordinación indebida hacia nadie, interno o externo al proceso (Alvarado Velloso 2003, 261).

\section{La imparcialidad judicial en los Sistemas Internacionales de Protección de los Derechos Humanos}

La imparcialidad judicial se encuentra consagrada como aspecto fundamental de la garantía del debido proceso legal en numerosos instrumentos internacionales de derechos humanos ${ }^{10}$, tales como la Convención Americana sobre Derechos Humanos (art. 8, inc. 1), el Pacto Internacional de los Derechos Civiles y Políticos (art. 14, inc. 1), la Declaración Americana de los Derechos del Hombre (art. 26), el Convenio Europeo de Derechos Humanos (art. 6, inc. 1).

\footnotetext{
10 Existen otros tratados internacionales más específicos que también refieren disposiciones relativas a la independencia e imparcialidad de los tribunales como: la Convención Internacional sobre la Protección de los Derechos de todos los Trabajadores Migratorios y de sus Familiares (Artículo 18.1); la Convención Internacional para la Protección de todas las Personas contra las Desapariciones Forzadas (Artículo 11.3); el Protocolo Adicional a los Convenios de Ginebra (Artículo 75.4) y el Protocolo Adicional relativo a la protección de las víctimas de los conflictos armados sin carácter internacional (Protocolo II) (Artículo 6.2).
} 
Si bien estos instrumentos no definen la imparcialidad judicial, los órganos internacionales de protección de los derechos humanos han desarrollado de forma extensa criterios para identificar supuestos en los cuales este principio se ve afectado.

\section{a. La imparcialidad en el Sistema Europeo de Protección de los Derechos Humanos}

El Convenio Europeo de Derechos Humanos establece los requisitos mínimos del debido proceso en su artículo 6 , cuyo inciso $1^{\circ}$ menciona expresamente la necesidad de que intervenga un tribunal independiente e imparcial ${ }^{11}$.

La Corte Europea de Derechos Humanos (en adelante, "Corte Europea" o "TEDH") ha dedicado numerosos pronunciamientos a la noción de imparcialidad. Uno de sus aportes más significativos ha sido distinguir una dimensión subjetiva, vinculada con las convicciones internas del juzgador y una dimensión objetiva, relacionada con aspectos de ponderación que rodean al caso y al juzgador más allá de sus sentimientos, creencias o favoritismos (Loianno 2020, 214).

Desde esta doble dimensión, la imparcialidad se juzga tanto por la conducta del juez en el caso concreto como por las garantías que el juez y el proceso brindan en forma suficiente para excluir cualquier duda legítima al respecto ${ }^{12}$.

\footnotetext{
${ }^{11}$ El inciso 1 del art. 6 dispone: "1. Toda persona tiene derecho a que su causa sea oída equitativa, públicamente y dentro de un plazo razonable, por un Tribunal independiente e imparcial, establecido por ley, que decidirá los litigios sobre sus derechos y obligaciones de carácter civil o sobre el fundamento de cualquier acusación en materia penal dirigida contra ella. La sentencia debe ser pronunciada públicamente, pero el acceso a la sala de audiencia puede ser prohibido a la prensa y al público durante la totalidad o parte del proceso en interés de la moralidad, del orden público o de la seguridad nacional en una sociedad democrática, cuando los intereses de los menores o la protección de la vida privada de las partes en el proceso así lo exijan 1011 o en la medida en que sea considerado estrictamente necesario por el tribunal, cuando en circunstancias especiales la publicidad pudiera ser perjudicial para los intereses de la justicia”.

12 Corte Europea de Derechos Humanos, Caso Thomann contra Suiza, Sentencia de 10 de junio de 1996, Repertorio de sentencias y resoluciones 1996-III, p. 815.
} 
La imparcialidad subjetiva del juez se presume en el caso concreto mientras no se pruebe lo contrario $^{13}$. La imparcialidad objetiva, por su parte, exige que el tribunal sea proactivo con las garantías que disipen cualquier resquemor al respecto ${ }^{14}$.

Existen varios pronunciamientos en los cuales el TEDH ha considerado afectada la garantía de imparcialidad desde una perspectiva subjetiva y objetiva.

1. En el caso Micallef $v$ s. Malta ${ }^{15}$ se planteó un problema de vecindad que involucraba el derecho de propiedad. Entre otras cuestiones, el actor invocó la ausencia de imparcialidad porque el presidente de la Corte de Apelación era pariente de quien representaba a la parte contraria. El TEDH estimó que "la apreciación objetiva consiste en exigir que, independientemente de la conducta personal del juez, ciertos hechos verificables autorizan a sospechar su imparcialidad"16. Si bien desde el punto de vista subjetivo no existían elementos para considerar ausencia de imparcialidad en el juez por ser pariente de uno de los abogados que intervenían en el proceso, no opina lo mismo cuando el análisis se hace desde el punto de vista objetivo. Según el Tribunal, si bien ese hecho no permite afirmar imparcialidad desde el punto de vista subjetivo, implica una apariencia objetiva de imparcialidad violatoria del artículo 6.1. de la Convención ${ }^{17}$.

2. En el caso Harabin V. Slovakya ${ }^{18}$, el Presidente del Tribunal Supremo de Eslovaquia (demandante) fue sometido a un proceso disciplinario ante el Tribunal Constitucional. El

\footnotetext{
${ }^{13}$ Corte Europea de Derechos Humanos, Caso Piersack vs. Belgium, Sentencia del 1 de octubre de 1982, párrs. 30-32, Series A no. 5; Caso Daktaras v. Lithuania, no. 42095/98 (Sect. 3) (bil.), ECHR 2000-X - (10.10.00)

${ }^{14}$ Ibídem, y De Cubber v. Belgium, sentencia del 26 de october de 1984, Series A no. 86.

${ }^{15}$ Corte Europea de Derechos Humanos, Caso Micallef Joseph v. Malta, Aplicación no. 17056/06, Sentencia del 15 de octubre de 2009.

${ }^{16}$ Ibídem, párrafo 96.

${ }^{17}$ Ibídem, párrafo 101.

${ }^{18}$ Corte Europea de Derechos Humanos, Caso Harabim v. Slovakya, Sentencia del 20 de noviembre de 2012, Sección III, Aplicación no. 58688/11.
} 
demandante recusó a cuatro de los trece jueces que debían conocer de su caso, de los cuales dos habían sido excluidos anteriormente de otros procedimientos en los que había participado, alegando que sus relaciones anteriores con los magistrados en cuestión implicaban un riesgo de parcialidad. El Tribunal Constitucional rechazó todas las recusaciones, pero sin responder a los argumentos por los que se había solicitado la exclusión de los jueces. Al decidir, TEDH consideró que un tribunal violó su deber de imparcialidad consagrado en el artículo 6.1 del Convenio Europeo porque sus integrantes habían sido excluidos previamente por falta de imparcialidad en casos anteriores relacionados contra el solicitante y no se habían disipado de forma convincente las dudas objetivas respecto de su imparcialidad.

3. En el caso Olújic v. Croacia ${ }^{19}$, el TEDH analizó la imparcialidad de los tres miembros del Consejo Nacional de la Magistratura en el marco de un procedimiento disciplinario seguido contra el demandante. El demandante alegaba que durante el procedimiento en cuestión los magistrados concedieron entrevistas, publicadas en dos periódicos nacionales diferentes, en las que expresaban su parcialidad. Uno de los magistrados había revelado públicamente, por ejemplo, que había votado en contra del nombramiento del demandante como juez. Otro de ellos había señalado que el demandante había cometido actividades indecentes, en las que había utilizado su influencia personal y sus contactos y que era una persona carente de experiencia y conocimiento. En el caso, el TEDH consideró que se afectó la imparcialidad objetiva porque los miembros del Consejo habían realizado manifestaciones públicas en contra del juez sometido a proceso que generaban una situación que podía

${ }_{19}$ Corte Europea de Derechos Humanos, Caso Olújic v. Croacia, Sentencia del 5 de febrero de 2009, (Sect.1) (Aplicación no. 22330/05). 
suscitar en el demandante dudas legítimas sobre su imparcialidad.

4. En el caso Sramek vs. Austria ${ }^{20}$, el TEDH analizó la imparcialidad de un órgano no jurisdiccional ("la autoridad regional") que negó el derecho de una ciudadana norteamericana a adquirir un terreno en Tirol para construir una vivienda vacacional. En el caso, el TEDH consideró que se violó la imparcialidad del artículo 6.1 de la Convención europea debido a la presencia en la autoridad regional de un funcionario que dependía jerárquicamente del Controlador y representaba los intereses del Gobierno, que era parte en el proceso. Para el TEDH "las apariencias revisten también importancia, y en el presente caso, un tribunal (la autoridad regional) cuenta entre sus miembros con una persona funcional y servicialmente subordinada a una de las partes, lo que conduce a dudar legítimamente de su independencia. Tal situación pone gravemente en causa la confianza que los tribunales deben inspirar en una sociedad democrática"21.

Puede notarse que, para el TEDH, la imparcialidad y la apariencia de imparcialidad constituyen un pilar fundamental del sistema de justicia y una pieza clave para fortalecer su credibilidad. Funciona al mismo tiempo como garantía del inculpado a tener un juicio justo y como garantía de los jueces, para que éstos puedan cumplir su mandato sin interferencias o presiones.

\section{b. La imparcialidad en el Sistema Universal de Protección de los Derechos Humanos}

En el sistema de derechos humanos de la Organización de Naciones Unidas, el derecho a un juicio imparcial está consagrado como un elemento fundamental de la protección de los derechos

\footnotetext{
${ }^{20}$ Corte Europea de Derechos Humanos, Caso Sramek vs. Austria, Sentencia del 22 de octubre de 1984, Affaire 8790/79.

${ }^{21}$ Ibidem, párrafo 42.
} 
humanos y un medio procesal para salvaguardar el imperio de la ley (Observación General Nro. 32 del Comité de Derechos Humanos 2007, párr. 2). La Declaración Universal de Derechos Humanos establece en su artículo 10: “Toda persona tiene derecho, en condiciones de plena igualdad, a ser oída públicamente y con justicia por un tribunal independiente e imparcial, para la determinación de sus derechos y obligaciones o para el examen de cualquier acusación contra ella en materia penal".

Por su parte, el artículo 14 del Pacto Internacional de los Derechos Civiles y Políticos tiene por objeto velar por la adecuada administración de la justicia, y, a tal efecto, garantiza una serie de derechos específicos; entre ellos, el derecho de toda persona a acceder a un tribunal competente, independiente e imparcial: "Toda persona tendrá derecho a ser oída públicamente y con las debidas garantías por un tribunal competente, independiente e imparcial, establecido por la ley, en la sustanciación de cualquier acusación de carácter penal formulada en contra de ella o para la determinación de sus derechos u obligaciones de carácter civil”.

Al interpretar el artículo 14 en su Observación General Nro. 32, el Comité de Derechos Humanos de Naciones Unidas ha dicho que "[e]l requisito de imparcialidad tiene dos aspectos. En primer lugar, los jueces no deben permitir que su fallo esté influenciado por sesgos o prejuicios personales, ni tener ideas preconcebidas en cuanto al asunto sometido a estudio, ni actuar de manera que indebidamente promueva los intereses de una de las partes en detrimento de los de la otra. En segundo lugar, el tribunal también debe parecer imparcial a un observador razonable. Por ejemplo, normalmente no puede ser considerado imparcial un juicio afectado por la participación de un juez que, conforme a los estatutos internos, debería haber sido recusado” (Comité de Derechos Humanos, 2007, párr. 21).

Esto implica que "tanto la imparcialidad de hecho como la apariencia de imparcialidad son fundamentales para que se 
mantenga el respeto por la administración de la justicia" (Manual de Amnistía Internacional 1998, 124).

Por su parte, los Principios Básicos relativos a la independencia de la Judicatura, adoptados por la Asamblea General de Naciones Unidas en 1990, establecen que los jueces deben resolver los asuntos que conozcan con imparcialidad, basándose en los hechos y en consonancia con el derecho, "sin restricción alguna y sin influencias, alicientes, presiones, amenazas o intromisiones indebidas, sean directas o indirectas, de cualesquiera sectores o por cualquier motivo" (Principio 2).

Asimismo, la resolución A/HRC/23/6 del Consejo de Derechos Humanos exhorta en su primer párrafo a todos los Estados a que "garanticen la independencia de los jueces y abogados y la objetividad e imparcialidad de los fiscales, así como su capacidad para desempeñar debidamente su cometido, mediante, entre otras cosas, la adopción de medidas efectivas de orden legislativo, policial o de otra índole, según proceda, para que puedan desempeñar sus funciones profesionales sin ningún tipo de injerencia, acoso, amenazas o intimidación”.

Por su parte, en el Informe de la Relatoría Especial sobre la Independencia de magistrados y Abogados de Naciones Unidas al Consejo de Derechos Humanos de 2018 (A/HRC/38/38), esta señaló que "todas las instituciones gubernamentales y de otra índole deben respetar y acatar la independencia de la judicatura, y adoptar todas las medidas apropiadas para que los jueces puedan resolver los asuntos que conozcan con imparcialidad y sin influencias, presiones o intromisiones indebidas" (párr. 9, énfasis añadido).

Sumado a lo anterior y refiriéndose exclusivamente a la segunda oración del numeral 1 del artículo 14 del PIDCP, el Comité de Derechos Humanos ha establecido que "[e]l requisito de la competencia, independencia e imparcialidad de un tribunal en el sentido del párrafo 1 del artículo 14 es un derecho absoluto que no puede ser objeto de excepción alguna" (Comité de Derechos 
Humanos, 2007, párr. 19). Por ello, compete a los Estados la obligación de "adoptar medidas concretas que garanticen la independencia del poder, y proteger a los jueces de toda forma de influencia política en la adopción de decisiones por medio de la Constitución o la aprobación de leyes" (Ibíd., párr. 19).

En esta línea, en el caso Ángel N. Oló Bahamonde v. Guinea EcuatoriaP2, el Comité expresó que "una situación en que las funciones y competencias del Poder Judicial y del Poder Ejecutivo no son claramente distinguibles o en la que este último puede controlar o dirigir al primero es incompatible con el concepto de un tribunal independiente e imparcial a tenor de lo dispuesto en el párrafo $1 \mathrm{del}$ artículo 14 del Pacto". De esto se deduce la necesidad de proteger a los jueces contra los conflictos de intereses y la intimidación.

Por su parte, el Relator Especial de Naciones Unidas para la Independencia de Jueces y Abogados, ha señalado que "[l]os principios de imparcialidad e independencia constituyen en todos los Estados los rasgos distintivos del fundamento y la legitimidad de la función judicial (...). Su inexistencia conduce a la denegación de justicia y resta credibilidad al proceso judicial”23.

\section{Diversos casos de falta de imparcialidad de los tribunales}

Existen diversos pronunciamientos de órganos del Sistema de Naciones Unidas en los cuales se ha considerado violentada la imparcialidad judicial. Por ejemplo, el Comité de Derechos Humanos en su visita a la República Democrática del Congo consideró que se atentó contra la imparcialidad cuando, antes de ser escuchado, el Presidente del Tribunal Supremo manifestó públicamente su apoyo a

\footnotetext{
22 Comité de Derechos Humanos, Caso Angel N. Oló Bahamonde v. Guinea Ecuatorial (1993), Comunicación No. 468/1991, U.N. Doc. CCPR/C/49/D/468/1991, Párr. 9.4 ${ }^{23}$ E/CN.4/Sub. 2/1985/18/Add. , párr. 75. (resaltado agregado).
} 
las destituciones de jueces que se hicieron mediante un Decreto Presidencial que se estaba cuestionando en el juicio ${ }^{24}$.

A su vez, en la Observación General Nro. 32, el Comité de Derechos Humanos advirtió que los tribunales especiales con "jueces sin rostro”, integrados por jueces anónimos, no satisfacen el requisito de que el tribunal debe ser imparcial e independiente porque el acusado desconoce la identidad y la condición de los jueces (Comité de Derechos Humanos, 2007, párr. 23).

A su vez, en la misma Observación General, el Comité señala que un proceso no es imparcial cuando "el acusado en un proceso penal enfrenta la expresión de una actitud hostil de parte del público o el apoyo de una parte en la sala del tribunal que es tolerada por el tribunal, con lo que se viola el derecho a la defensa o el acusado queda expuesto a otras manifestaciones de hostilidad con efectos similares" (Comité de Derechos Humanos, 2007, párr. 25).

\section{c. La imparcialidad en el Sistema Interamericano de Derechos Humanos}

En el Sistema Interamericano el principio de imparcialidad judicial se encuentra consagrado como una de las garantías del debido proceso en el artículo 8, inc. 1, de la Convención Americana, que dispone que "[t]oda persona tiene derecho a ser oída, con las debidas garantías y dentro de un plazo razonable, por un juez o tribunal competente, independiente e imparcial"25.

El derecho a contar con un juez imparcial constituye la garantía de que la decisión será adoptada con base en las razones que el

\footnotetext{
${ }^{24}$ Naciones Unidas. Comité de Derechos Humanos. Comunicación No. 933/2000: Democratic Republic of Congo, CCPR/C/78/D/933/2000, 19 de septiembre de 2003.

25 Originariamente, la Declaración Americana sobre los Derechos y Deberes del Hombre establece en su artículo XXVI: "Toda persona acusada de delito tiene derecho a ser oída en forma imparcial y pública, a ser juzgada por tribunales anteriormente establecidos de acuerdo con leyes preexistentes y a que no se le impongan penas crueles, infamantes o inusitadas".
} 
derecho otorga y no con base en otros criterios extrajurídicos (CIDH, 2017, párrafo 102).

La Corte Interamericana ha ampliado el alcance textual de la garantía de imparcialidad del artículo 8. Además de los jueces, cualquier otro órgano del Estado que ejerza funciones de carácter materialmente jurisdiccional, es decir, cualquier autoridad pública, judicial o no judicial, que decida sobre los derechos o intereses de las personas a través de sus resoluciones está obligado a la imparcialidad $^{26}$.

La imparcialidad es, además de un derecho de quien es parte de un proceso, una garantía para que los jueces puedan cumplir con su mandato de garantizar los derechos fundamentales y el imperio de la ley. En tal sentido, en el caso Norin Catriman la Corte Interamericana dejó en claro que "la independencia e imparcialidad no sólo se traduce como un derecho a favor de la persona que es sometida a un proceso, sino también como una garantía para los juzgadores, es decir, para que los mismos tengan las condiciones, tanto institucionales, como personales para hacer cumplir ese mandato"27.

De manera similar a lo expuesto en el Sistema Universal, la Corte IDH ha señalado que la garantía de imparcialidad exige "que la autoridad que interviene se aproxime a los hechos careciendo, de manera subjetiva, de todo prejuicio y, ofreciendo garantías suficientes de índole objetiva que permitan desterrar toda duda que el justiciable o la comunidad puedan albergar respecto de la ausencia de

\footnotetext{
${ }^{26}$ Cfr. Corte IDH, Caso Yatama Vs. Nicaragua, Excepciones Preliminares, Fondo, Reparaciones y Costas, Sentencia de 23 de junio de 2005, Serie C No. 127, párr. 149. En el caso, la Corte dijo: “149. Todos los órganos que ejerzan funciones de naturaleza materialmente jurisdiccional tienen el deber de adoptar decisiones justas basadas en el respeto pleno a las garantías del debido proceso establecidas en el artículo 8 de la Convención Americana El artículo 8.1 de la Convención, que alude al derecho de toda persona a ser oída por un "juez o tribunal competente" para la "determinación de sus derechos", es igualmente aplicable al supuesto en que alguna autoridad pública, no judicial, dicte resoluciones que afecten la determinación de tales derechos (...)".

27 Corte IDH, Caso Norin Catriman y otros vs. Chile, Sentencia de 29 de mayo de 2014, Párrafo 14.
} 
imparcialidad"28. Una derivación concreta de la regla consiste en la facultad de recusar que tienen las partes sobre quien juzga ${ }^{29}$.

La Corte IDH también ha considerado vulnerado el principio de imparcialidad en aquellos casos en los cuales civiles acusados por la presunta comisión de delitos graves han sido juzgadas penalmente por jueces sin rostros o por tribunales militares ${ }^{30}$.

Finalmente, es interesante notar que los derechos de los jueces (el derecho a participar en la política, a la libertad de expresión, el derecho de reunión, etcétera) pueden verse limitados con el objetivo de garantizar la independencia e imparcialidad de sus actuaciones ${ }^{31}$. Tal es la importancia que se le asigna a su rol. Por ejemplo, si bien el ejercicio de su libertad de expresión es indispensable para explicar a la sociedad, por ejemplo, cuestiones de interés público, puede limitarse cuando existe un deber de secreto profesional respecto de la información confidencial que hayan obtenido en el desempeño de sus funciones, a menos que se trate de audiencias públicas, y no deben

28 Corte IDH, Caso Apitz Barbera y otros ("Corte Primera de lo Contencioso Administrativo") vs. Venezuela, Excepción Preliminar, Fondo, Reparaciones y Costas, Sentencia de 5 de agosto de 2008, Serie C No 182, párr. 56; Caso del Tribunal Constitucional vs. Perú, Fondo, Reparaciones y Costas, Sentencia de 31 de enero de 2001, Serie C No. 71, párr. 73.

29 Corte IDH, Caso Apitz Barbera y otros ("Corte Primera de lo Contencioso Administrativo") vs. Venezuela, Excepción Preliminar, Fondo, Reparaciones y Costas, Sentencia de 5 de agosto de 2008, Serie C No. 182, párrs. 59-67, página 253.

${ }^{30}$ En el caso Cantoral Benavides c. Perú ante la Corte IDH, la Comisión alegó que se habían violado garantías procesales en perjuicio del señor Cantoral Benavides tras ser juzgado, tanto en el fuero privativo militar como en el fuero común, por jueces sin rostro, carentes de la independencia e imparcialidad exigidas en el artículo 8.1 de la $\mathrm{CADH}$. La Corte consideró que "la imparcialidad resulta afectada por el hecho de que las fuerzas armadas tengan la doble función de combatir militarmente a los grupos insurgentes y de juzgar e imponer penas a los miembros de dichos grupos" (Sentencia de fondo del 18 de agosto de 2000, párrafo 141)

En igual sentido, en el caso Lori Berenson contra Perú, la Corte IDH sostuvo que “[...] los tribunales militares que juzgaron a la presunta víctima por traición a la patria no satisfacen los requerimientos inherentes a las garantías de independencia e imparcialidad establecidas por el artículo 8.1 de Convención Americana, como elementos esenciales del debido proceso legal" (Sentencia de 25 de noviembre de 2004, Fondo, Reparaciones y Costas, párrafo 146).

${ }^{31}$ Corte IDH, Caso López Lone y otros vs. Honduras, Excepción Preliminar, Fondo, Reparaciones y Costas, Sentencia de 5 de octubre de 2015, Serie C No. 3025, párrafo 171. 
testificar sobre tales asuntos ${ }^{32}$. Otro ejemplo son las restricciones a la participación de los jueces en las actividades político-partidistas, para garantizar su independencia e imparcialidad ${ }^{33}$.

\section{La intervención del juez natural como garantía del debido proceso en los procesos políticamente expuestos}

Indisolublemente vinculado con la imparcialidad se encuentra la garantía del "juez natural”. Suele entenderse por juez natural aquel preexistente al hecho del proceso ${ }^{34}$.

Esta garantía, en buena medida, permite la imparcialidad del tribunal y funciona como una herramienta indispensable frente a la posible arbitrariedad de que a un acusado se le asigne, con posterioridad al acaecimiento del hecho que se le imputa, "un juez especialmente designado, no para juzgarlo imparcialmente, sino para perjudicarlo" (Cafferata Nores, 2011, 109). La idea del juez natural busca evitar la parcialidad que supondría la formación de tribunales especiales, creados luego de los hechos, para juzgar a ciertas personas.

A través de su jurisprudencia, la Corte IDH ha explicado la garantía del juez natural, aclarando sus implicancias y alcances.

En primer lugar, ha resaltado que es crucial el nombramiento previo al hecho. En el caso Apitz Barbera, la Corte señaló que "el artículo 8.1 de la Convención garantiza el derecho a ser juzgado por

\footnotetext{
32 Principios Básicos de Naciones Unidas relativos a la independencia de la judicatura de Naciones Unidas, op. cit., Principio 15.

${ }^{33}$ Cfr. Corte IDH, Caso López Lone y otros vs. Honduras, Excepción Preliminar, Fondo, Reparaciones y Costas, Sentencia de 5 de octubre de 2015, Serie C No. 3025 párrafo 172. ${ }_{34}$ Cfr. Corte IDH, Caso Herrera Ulloa vs. Costa Rica, Excepciones Preliminares, Fondo, Reparaciones y Costas, Sentencia de 2 de julio de 2004. Serie C No. 107, párr. 169.
} 
un tribunal competente (...) establecido con anterioridad a la ley"35. Según la Corte, ello implica que "toda persona tiene derecho a ser juzgada por tribunales de justicia ordinarios con arreglo a procedimientos legalmente establecidos, razón por la cual el Estado no debe crear tribunales que no apliquen normas procesales debidamente establecidas para sustituir la jurisdicción que corresponda normalmente a los tribunales ordinarios" 36 .

En segundo lugar, la Corte IDH ha destacado la necesidad de una ley formal que dé origen al tribunal. Tal como lo explicitó en el caso Barreto Leiva, “[e]l juez natural deriva su existencia y competencia de la ley, la cual ha sido definida por la Corte como la norma jurídica de carácter general, ceñida al bien común, emanada de los órganos legislativos constitucionalmente previstos y democráticamente elegidos, y elaborada según el procedimiento establecido por las constituciones de los Estados Partes para la formación de las Leyes" (párrafo 76).

La Corte IDH ha considerado que se viola la garantía del juez natural, por ejemplo, en casos en los cuales tribunales militares han juzgado civiles asumiendo competencias que corresponden a la justicia ordinaria ${ }^{37}$ o cuando tribunales militares han juzgado militares por la comisión de delitos comunes ${ }^{38}$.

En el caso Castillo Petruzzi, la Corte entendió que "el procesamiento de civiles por el delito de traición a la patria en este fuero, supone excluir al juez natural para el conocimiento de estas causas. En efecto, la jurisdicción militar no es la naturalmente aplicable a civiles que carecen de funciones militares" (párr. 128). En

35 Corte IDH. 2008. Caso Apitz Barbera y otros ("Corte Primera de lo Contencioso Administrativo") vs. Venezuela, Sentencia del 5 de agosto de 2008, Serie C No. 182 (énfasis añadido).

36 Ibídem, párr. 50.

37 Corte IDH, Caso Castillo Petruzzi y otros vs. Perú, Sentencia del 30 de mayo de 1999 , Serie C No 52132. En igual sentido, Corte IDH, Caso Cantoral Benavides vs. Perú, Sentencia de 18 de agosto de 2000, (Fondo), párr. 112.

${ }^{38}$ Corte IDH, Caso Las Palmeras vs. Colombia, Sentencia de 6 de diciembre de 2001, (Fondo). 
el mismo sentido, agregó que "[c]uando la justicia militar asume competencia sobre un asunto que debe conocer la justicia ordinaria se ve afectado el derecho al juez natural" (párr. 128).

También ha establecido que se viola el principio del juez natural en los casos de juzgamientos por tribunales especiales o jueces ad hoc. En el caso Ivcher Bronstein, la Corte IDH consideró que el Estado violó el principio del juez natural, y, en consecuencia, las garantías judiciales del artículo 8.1 de la $\mathrm{CADH}$, “[a]l crear Salas y Juzgados Transitorios Especializados en Derecho Público y designar jueces que integraran los mismos, en el momento en que ocurrían los hechos del caso sub judice” (párr. 114). Adicionalmente, en el caso Baena, en virtud de la Ley 25, se modificó simultáneamente a una serie de despidos de empleados del Estado, la legislación que regía el procedimiento y la jurisdicción especial en lo laboral que debía entender en ellos, trasladándose a lo contencioso administrativo. La Corte IDH entendió que el Estado violó la garantía del juez natural al desplazar con posterioridad a los hechos la competencia de la jurisdicción laboral a la contencioso-administrativa, "[d]ebido a esta ley los trabajadores estatales no tuvieron el derecho de ser juzgados por tribunales establecidos con anterioridad, se les sometió a procesos ante tribunales que al momento de los hechos no eran los competentes para juzgarlos" (párr. 116, ap. I). En definitiva, en ambos casos, las cuestiones a decidir fueron sometidas a autoridades distintas a aquellas previamente designadas para conocerlas $\mathrm{y}$ resolverlas.

A diferencia del Sistema Interamericano, el Sistema Universal de Protección de los Derechos Humanos no ha desarrollado jurisprudencia significativa en torno a la garantía del juez natural. Sin embargo, el Comité de Derechos Humanos parece ser algo más flexible en relación a los tribunales especiales, y ha considerado que no en todos los casos serían incompatibles con el artículo $14.1 \mathrm{del}$ Pacto Internacional de los Derechos Civiles y Políticos. 
En su Observación General Nro. 13 sobre "Administración de justicia (artículo 14)" del año 1984 reconoce que las garantías del artículo 14 del PIDCP se aplican a todos los tribunales y cortes de justicia, ya sean ordinarios o especiales. Sin embargo, entiende que "las condiciones que estipula indican claramente que el procesamiento de civiles por tales tribunales (especiales) debe ser muy excepcional y ocurrir en circunstancias que permitan verdaderamente la plena aplicación de las garantías previstas en el artículo 14 (...) En algunos países, esos tribunales militares y especiales no proporcionan las garantías estrictas para la adecuada administración de la justicia, de conformidad con las exigencias del artículo 14, que son fundamentales para la eficaz protección de los derechos humanos" (párr. 4).

Además, en varias decisiones ${ }^{39}$, el Comité ha expresado su preocupación por la creación y utilización de tribunales especiales, aunque sin referirse expresamente a la garantía del juez natural.

La creación de comisiones o tribunales especiales para juzgar ciertos delitos suele identificar a los procesos políticamente expuestos. En ocasiones el poder político considera que hay ciertos adversarios, rivales o "enemigos del Estado" a los que conviene neutralizar, pero da una apariencia de legalidad a la persecución a través de un tribunal que no respeta los requisitos del juez natural (Amnistía Internacional 2014, 242).

${ }^{39}$ CDH, Comunicación No. 328/1988, Roberto Zelaya Blanco v. Nicaragua (Fecha 20 de julio de 1994), CCPR/C/51/D/328/1988. Ver también Observaciones finales del Comité de Derechos Humanos sobre Nigeria, documentos de la ONU CCPR/C/79/Add.65 y CCPR/C/79/Add.64; Observaciones finales del Comité de Derechos Humanos sobre Marruecos, documentos de la ONU A/47/40, paras. 48-79 y CCPR/C/79/Add. 113, párr. 18; entre otras. 


\section{El juez natural debe ser competente para juzgar los casos Ilevados a su conocimiento}

En otras oportunidades, la imparcialidad se vulnera de manera más velada aún. Ya no se crea un tribunal especial, sino que un tribunal incompetente es el que se arroga el conocimiento de la causa. En estos casos, el juzgamiento por tribunales establecidos con anterioridad por ley se vincula estrechamente con la garantía del juez competente, pero analíticamente son conceptos distinguibles.

El artículo 8.1 de la Convención Americana dispone que toda persona tiene derecho a ser juzgado por un juez o tribunal previamente establecido por ley, que debe ser, además, competente ${ }^{40}$. La Corte IDH se ha referido a esta relación en los siguientes términos: “[p]ara que se respete el derecho al juez natural no basta con que esté establecido previamente por la ley cuál será el tribunal que atenderá una causa y se le otorgue competencia" ${ }^{41}$.

La garantía del "juez competente" del artículo 8.1 de la CADH se refiere, según lo ha entendido la propia Corte IDH, a la garantía de ser juzgado por un órgano que "actúe en los términos del procedimiento legalmente previsto para el conocimiento y la resolución del caso que se le somete" 42 . En cada caso, la competencia de los tribunales debe ser fijada a través de los medios establecidos a nivel interno de cada Estado $^{43}$.

La competencia que evoca la Convención Americana no se refiere únicamente a la de los órganos judiciales sino también "a cualquier autoridad pública, sea administrativa, legislativa o judicial,

\footnotetext{
${ }^{40}$ En su parte pertinente, el artículo 8.1 dispone que " 1 . Toda persona tiene derecho a ser oída, con las debidas garantías y dentro de un plazo razonable por un juez o tribunal competente, independiente e imparcial, establecido con anterioridad a la ley".

${ }^{41}$ Corte IDH, Caso Palamara Iribarne vs. Chile, Sentencia de 22 de noviembre de 2005, párr. 125.

${ }^{42}$ Corte IDH. Caso Yvon Neptune vs. Haití, sentencia del 6 de mayo de 2008, Fondo, Reparaciones y Costas, serie C Nro. 18017.

${ }^{43}$ Ibídem, párr. 81.
} 
que a través de sus resoluciones determine derechos y obligaciones de las personas"44. En este sentido, en el caso Tribunal Constituciona $^{45}$, la Corte dejó en claro que la garantía de la competencia es aplicable a todas aquellas situaciones en las que alguna autoridad pública, no judicial, dicte resoluciones que afecten la determinación de tales derechos ${ }^{46}$.

Las diferencias conceptuales entre juez natural y juez competente pueden ser algo difusas en la jurisprudencia internacional. Son conceptos estrechamente relacionados, pero conviene diferenciarlos. El juez natural es aquel establecido previamente. El juez competente es aquel al que la ley le confiere la potestad de juzgar en un caso concreto, en arreglo al fuero, tiempo y lugar. Por ello, un juez competente puede no ser natural, si la ley que lo instituyó es posterior al acaecimiento del hecho ${ }^{47}$.

Nuevamente, la incompetencia de los tribunales que intervienen en procesos políticamente expuestos genera descrédito del poder judicial en la sociedad. Funcionan como jueces a la carta de las autoridades políticas.

${ }^{44}$ Caso Ivcher Bronstein vs. Perú, Fondo, reparaciones y costas, Sentencia del 6 de febrero de 2001, Serie C No. 74, párr. 104.

${ }^{45}$ Corte IDH, Caso del Tribunal Constitucional vs. Perú, Fondo, reparaciones y costas, Sentencia del 31 de enero de 2001, serie C No. 71.

46 En el mismo sentido, Corte IDH, Caso López Álvarez vs. Honduras, fondo, reparaciones y costas, sentencia del 1 de febrero de 2006, serie C No. 141, párr. 148. Corte IDH. Caso Apitz Barbera y otros (Corte Primera de los Contencioso Administrativo) vs. Venezuela, excepción preliminar, fondo, reparaciones y costas, Sentencia del 5 de agosto de 2008, serie C No. 182, párr. 50.

${ }^{47}$ En el caso Ivcher Bronstein vs. Perú, la Corte Interamericana consideró que el Estado violó el principio del juez natural al crear Salas y Juzgados Transitorios Especializados en Derecho Público (con competencia para conocer los recursos contra la decisión que dejó sin efecto la nacionalidad del Sr. Ivcher), en el momento en el que ocurrían los hechos. Es decir, el Juzgado era competente pero no garantizaba el derecho de la víctima a ser oído por un tribunal establecido con anterioridad por ley. Sentencia del 11 de febrero de 2011, cfr. párr. 114. 


\section{La igualdad en los procesos políticamente expuestos}

Un aspecto que también suele ser conflictivo en los procesos políticamente expuestos es el de la igualdad procesal, especialmente durante la investigación.

El principio de la igualdad procesal — también llamado igualdad de armas - supone "equiparar las posibilidades del imputado respecto de las del acusador" (Maier 2004, 577). Ferrajoli ha precisado el concepto: "para que la contienda se desarrolle lealmente y con igualdad de armas, es necesaria, por otro lado, la perfecta igualdad de las partes: en primer lugar, que la defensa esté dotada de la misma capacidad y de los mismos poderes que la acusación; en segundo lugar, que se admita su poder contradictor en todo momento y grado del procedimiento" (Ferrajoli 2005, 614). Esta misma idea es tomada por la Corte IDH, que ha establecido que en todo proceso debe existir un equilibrio entre las partes, lo que supone la contradicción ${ }^{48}$.

En el proceso penal, sin embargo, hay una etapa en la que la jurisprudencia ha permitido limitar excepcionalmente la contradicción, pues a la parte acusada no se le permite acceder a las pruebas que se obtienen. Esto ocurre en la etapa investigativa, que suele garantizar cierto nivel de restricción, que — presuntamenteayuda al investigador a encontrar la verdad. La Convención Americana lo contempla en el artículo 8, inc. 2: "El proceso penal debe ser público, salvo en lo que sea necesario para preservar los intereses de la justicia”.

Como puede verse, esta posibilidad está planteada como una excepción al principio de publicidad del proceso. Por tanto, sólo

\footnotetext{
${ }^{48} \mathrm{Cft}$. Corte IDH, Caso Palamara Iribarne vs. Chile, Sentencia de 22 de noviembre de 2005 ,

(Fondo Reparaciones y Costas), párr. 114. La Corte IDH ha establecido que en todo proceso deben concurrir los elementos necesarios para "que exista el mayor equilibrio entre las partes, para la debida defensa de sus intereses y derechos. Esto implica, entre otras cosas, que rija el principio de contradictorio", párr. 178.
} 
puede ser interpretada de manera restrictiva. De otra manera, la igualdad de armas explicada se ve severamente lesionada.

\section{d. El secreto de sumario y la igualdad de armas en la jurisprudencia internacional de derechos humanos}

La Corte IDH se ha referido a las restricciones de un acusado para intervenir en el proceso en los casos Palamara Iribarne ${ }^{49}$ y Barreto Leiva $a^{50}$.

El primero tiene como víctima a Antonio Palamara Iribarne, quien trabajaba como asesor técnico de las Fuerzas Armadas de Chile. Palamara Iribarne escribió el libro "Ética y Servicios de Inteligencia”, que fue censurado. Además, se le inició un proceso penal, en el que las diligencias preliminares fueron reservadas. La Corte IDH entendió que "[d] esde el inicio de las primeras diligencias de un proceso deben concurrir las máximas garantías procesales para salvaguardar el derecho a defenderse durante todo el proceso que tiene una persona acusada de cometer un delito, de conformidad con el artículo 8.2.d) de la Convención”. Por ello, una regla amplia de secreto de sumario "es contraria a la garantía de publicidad que debe tener el proceso penal de acuerdo con el artículo 8.5 de la Convención, no condice con el carácter restrictivo que tiene la figura del secreto de sumario"51.

El caso Barreto Leiva versa sobre diversas vulneraciones de las garantías judiciales de quien fuera Director General Sectorial de Administración y Servicios del Ministerio de la Secretaría de la Presidencia de Venezuela. El Sr. Barreto Leiva fue condenado en 1989 por el delito de malversación genérica agravada en grado de complicidad.

$\mathrm{Al}$ ser investigado, Barreto Leiva no tuvo acceso al expediente hasta que fue privado de su libertad en forma preventiva. La Corte

\footnotetext{
${ }^{49}$ Corte IDH, Caso Palamara Iribarne vs. Chile, cit.

${ }^{50}$ Corte IDH, Caso Barreto Leiva vs. Venezuela, cit.

${ }^{51}$ Corte IDH, Caso Palamara Iribarne vs. Chile, cit., parr. 178.
} 
IDH contempló diversos aspectos de la cuestión del secreto de sumario. Por un lado, reconoció que el Estado debe ser eficiente en sus investigaciones ${ }^{52}$. Por otro lado, reconoció que el poder estatal no es ilimitado. Es preciso que el Estado actúe "dentro de los límites y conforme a los procedimientos que permiten preservar tanto la seguridad pública como los derechos fundamentales de la persona humana"53. Por ello debe garantizar la contradicción, y si quiere limitar este derecho debe "argüir de manera fundada cuál es el fin legítimo que pretende conseguir y demostrar que el medio a utilizar para llegar a ese fin es idóneo, necesario y estrictamente proporcional. Caso contrario, la restricción del derecho de defensa del individuo será contraria a la Convención" ${ }^{54}$.

En este sentido, para la Corte, una norma que habilitara el secreto de sumario en todo caso para el investigado no privado de libertad, sin contemplar las características del caso concreto, era contraria al art. 8.2.c de la Convención ${ }^{55}$.

Puede notarse que, para la Corte, el secreto de sumario realmente puede alterar la igualdad de armas en el proceso. Publicidad y garantías procesales del acusado son cuestiones indisolublemente relacionadas.

El carácter de secreto también suele caracterizar los fines políticos de ciertos procesos judiciales, en los que se avanza contra una persona. La publicidad del proceso penal fue una de las conquistas frente a la justicia contaminada de política y teñida de arbitrariedad (Caro Coria 2006, 1040).

\footnotetext{
52 Corte IDH, Caso Barreto Leiva vs. Venezuela, op. cit., párr. 53.

53 Ibídem, citando Caso Bulacio vs. Argentina, Sentencia de 18 de septiembre de 2003, Serie C No. 100, párr. 124; Caso Juan Humberto Sánchez vs. Honduras, Sentencia de 7 de junio de 2003, Serie C No. 99, párr. 86.

${ }^{54}$ Ibídem, párr. 55. Cfr. párr. 53.

55 Párr. 56.
} 


\section{Las escuchas e interceptaciones telefónicas en los sistemas internacionales de protección de los derechos humanos y su vinculación con los procesos judiciales}

En los años recientes los avances tecnológicos dieron lugar a una modalidad de intervención sobre estos procesos que se ha verificado con frecuencia: la difusión de conversaciones entre abogados y clientes. Estas comunicaciones han tomado estado público, y muchas veces son utilizadas para obtener un fin político ajeno al proceso, a la vez que presionan sobre la tarea de jueces, fiscales y abogados involucrados en los casos. La facilidad con la que el registro de estas comunicaciones se hace público reclama prestar una atención especial a la protección de la confidencialidad en las comunicaciones entre abogados y acusados. Este es un aspecto fundamental de las garantías judiciales protegidas por el derecho internacional de los derechos humanos.

Los sistemas internacionales de protección de los derechos humanos admiten, en determinadas circunstancias, que los Estados establezcan ciertas restricciones a los derechos a la intimidad y a la protección de la vida privada, por ejemplo, permitiendo la interceptación de comunicaciones privadas. Sin embargo, coinciden en que toda restricción debe ser excepcional, estar prevista por ley y autorizada por un tribunal competente para velar que se respeten los derechos humanos afectados.

\section{a. Las escuchas e interceptaciones telefónicas en el sistema europeo}

En el Sistema Europeo, el Convenio Europeo de Derechos Humanos protege el derecho al respeto a la vida privada y familiar en su artículo 8, en los siguientes términos:

1. Toda persona tiene derecho al respeto de su vida privada y familiar, de su domicilio y de su correspondencia. 
2. No podrá haber injerencia de la autoridad pública en el ejercicio de este derecho sino en tanto en cuanto esta injerencia esté prevista por la ley y constituya una medida que, en una sociedad democrática, sea necesaria para la seguridad nacional, la seguridad pública, el bienestar económico del país, la defensa del orden y la prevención de las infracciones penales, la protección de la salud o de la moral, o la protección de los derechos y las libertades de los demás.

La norma protege expresamente las comunicaciones privadas de injerencias de la autoridad pública. Al interpretar esta disposición, en el caso Copland c. Reino Unido ${ }^{56}$, el TEDH consideró que las llamadas telefónicas, los correos electrónicos y la navegación por internet se encuentran comprendidas en las nociones de vida privada y de correspondencia tuteladas por el artículo 8.1 del Convenio Europeo y, por ende, están protegidas frente a injerencias arbitrarias.

En varias oportunidades, el TEDH ha tenido que valorar la interceptación de comunicaciones telefónicas y correos electrónicos por autoridades públicas a la luz del artículo 8 del Convenio Europeo. Esta valoración se ha centrado en tres requisitos fundamentales. Primero, si existe una injerencia de una autoridad pública. Segundo, si la medida se encuentra prevista o habilitada por ley. Finalmente, si la medida persigue un objetivo legítimo y es necesaria en una sociedad democrática.

En cuanto a la determinación de la existencia de una injerencia de una autoridad pública, el TEDH ha considerado que "la recogida y almacenamiento de información personal relativa a las llamadas telefónicas, correo electrónico y navegación por Internet" constituye una injerencia en su derecho al respeto de su vida privada y su correspondencia" 57 .

56 TEDH, Caso Copland vs. Reino Unido, Sentencia del 3 de septiembre de 2007, Demanda núm. 62617/2000.

57 Ídem, párr. 44. 
Respecto de la previsión legal de las interceptaciones telefónicas, el Tribunal ha reiterado en su jurisprudencia que la expresión "prevista por la ley" del artículo 8.1 del Convenio Europeo implica que "la legislación interna debe ofrecer una cierta protección contra las injerencias arbitrarias de los poderes públicos a los derechos garantizados por el párrafo 1. Esta expresión no solo impone el respeto de la legislación interna, sino que se refiere asimismo a la calidad de la ley, que debe ser conforme a los principios que rigen el Estado de derecho. Para cumplir la exigencia de previsibilidad, la ley debe utilizar términos lo suficientemente claros para indicar a todos, de forma suficiente en qué circunstancias y bajo qué condiciones capacita al poder público para tomar tales decisiones"58.

En consecuencia, no es suficiente que una ley autorice medidas de vigilancia secreta; es preciso que, además, concrete los presupuestos específicos habilitantes de la interceptación para evitar posibles abusos ${ }^{59}$. En otras palabras, la ley debe ser clara y precisa en cuanto a las circunstancias en las que la autoridad puede ordenar la interceptación y bajo qué condiciones (duración, extensión, razones, etc.), para ofrecer previsibilidad sobre el ejercicio de este tipo de medidas por parte de las autoridades estatales.

Según la jurisprudencia del TEDH, entonces, viola el artículo 8 del Convenio Europeo: (i) toda medida de vigilancia secreta ordenada sin sustento en una ley; o (ii) una medida basada en regulaciones administrativas o en una norma legal general que no incluya con claridad sus fines y modo de ejercicio por parte de las autoridades. Estas exigencias legales son aplicables también a los controles sobre las comunicaciones telefónicas que, aunque sin revisar su contenido, afecten sus elementos esenciales, como el destinatario y su duración ${ }^{60}$.

\footnotetext{
58 TEDH, Caso Copland vs. Reino Unido, op. cit., ap. 45 y 46; TEDH, Caso Harfold vs. Reino Unido, 1997, ap. 49 y TEDH, Caso Malone vs. Reino Unido, 1984, ap. 67.

59 TEDH, Caso Klass y otros c. Alemania, Sentencia del 6 de septiembre de 1978, párr 50. 60 TEDH, Malone c. Reino Unido, 1984; TEDH, Valenzuela Contreras c. España, 1988; TEDH, Copland c. Reino Unido, 2007.
} 
Finalmente, el TEDH ha reiterado que las medidas de vigilancia secretas deben perseguir un objetivo legítimo (la seguridad nacional, la defensa del orden y la prevención del delito) y ser necesarias en una sociedad democrática ${ }^{61}$. Al respecto, el TEDH ha señalado que "el poder de vigilar en secreto a los ciudadanos según el Convenio sólo se tolera en la medida estrictamente necesaria para la protección de las instituciones democráticas" ${ }^{2}$.

\section{b. La protección de la intimidad en el Sistema Interamericano de Derechos Humanos}

La Convención Americana sobre Derechos Humanos, en su artículo 11.2, establece que "Nadie puede ser objeto de injerencias arbitrarias o abusivas en su vida privada, en la de su familia, en su domicilio o en su correspondencia, ni de ataques ilegales a su honra o reputación".

La Corte IDH también ha tenido la oportunidad de valorar la legitimidad de interceptaciones telefónicas a la luz de la Convención Americana. En el caso Escher ${ }^{63}$, la Corte tuvo que resolver si la interceptación, grabación y divulgación de conversaciones telefónicas privadas de las víctimas constituyó una injerencia arbitraria de la autoridad pública, y, por tanto, una violación al artículo 11 de la CADH.

En esa oportunidad, la Corte señaló que "el ámbito de la privacidad se caracteriza por quedar exento e inmune a las invasiones o agresiones abusivas o arbitrarias por parte de terceros o de la autoridad pública". Sin embargo, no se trata de un derecho de carácter absoluto, sino que admite restricciones siempre que cumplan con determinados requisitos. Al respecto, la Corte advirtió que "la admisión de la injerencia queda condicionada a enérgicos

\footnotetext{
${ }^{61}$ Ibídem, párr. 60.

62 Ibídem, párr. 42.

${ }^{63}$ Corte IDH. 2009. Caso Escher y Otros vs. Brasil, Sentencia de 6 de julio de 2009. Serie C, No. 200.
} 
requisitos, que marcan la frontera —en una sociedad democráticaentre el ejercicio legítimo de la autoridad y el abuso intolerable del poder" 64 .

En el caso, al analizar si las interceptaciones constituyeron o no una injerencia arbitraria en los términos del artículo 11.2 de la $\mathrm{CADH}$, la Corte señaló lo siguiente:

Como las conversaciones telefónicas de las presuntas víctimas eran de carácter privado y dichas personas no autorizaron que fueran conocidas por terceros, su interceptación por parte de agentes del Estado constituyó una injerencia en su vida privada. Por tanto, la Corte debe examinar si dicha injerencia resulta arbitraria o abusiva en los términos del artículo 11.2 de la Convención o si es compatible con dicho tratado. Como ya se indicó, para que resulte conforme a la Convención Americana una injerencia debe cumplir con los siguientes requisitos: a) estar prevista en ley; b) perseguir un fin legítimo, y c) ser idónea, necesaria $y$ proporcional. En consecuencia, la falta de alguno de dichos requisitos implica que la injerencia es contraria a la Convención ${ }^{65}$.

Para examinar si una interceptación telefónica cumple el requisito de legalidad, la Corte consideró que medida debe estar fundada en una ley (en sentido formal y material), que debe ser precisa e indicar reglas claras y detalladas sobre la materia, con las circunstancias en las que puede ser adoptada, las personas autorizadas a solicitarla, a ordenarla y a llevarla a cabo, el procedimiento a seguir, entre otros elementos ${ }^{66}$.

En el caso, el Tribunal entendió que las interceptaciones no cumplieron con el requisito de legalidad y por ello no fue necesario continuar con el análisis de los requisitos de finalidad y necesidad de

\footnotetext{
${ }^{64}$ Ibídem, voto concurrente del Juez Sergio García Ramírez, párr. 11.

${ }^{65}$ Ibídem, párr. 129.

${ }^{66}$ Ibídem, párr. 131.
} 
la medida. No obstante, de las alegaciones de la Comisión Interamericana surgen algunas precisiones al respecto. Según el organismo, "[l] as fuerzas de seguridad del Estado pueden verse en la necesidad de realizar operaciones de inteligencia, de acuerdo con la ley, para combatir el delito y proteger el orden constitucional (objetivo legítimo). Sin embargo, tales acciones son legítimas cuando constituyen una medida estrictamente necesaria para salvaguardar las instituciones democráticas y existen garantías adecuadas contra los abusos (necesidad)". En el caso, la Comisión entendió que la intervención de las comunicaciones telefónicas de las víctimas se llevó a cabo con un objetivo ilegítimo "de ejercer un control sobre sus actividades asociativas, [y] la publicación de dichas comunicaciones, resguardadas por secreto de justicia, fue efectuad[a] expresamente para deslegitimar el trabajo de las asociaciones que integraban las víctimas".

Ambos sistemas admiten entonces ciertas intervenciones de la autoridad pública en las conversaciones privadas. Sin embargo, también exigen el cumplimiento de estrictos requisitos y conforme a rigurosos procedimientos y bajo el control de las autoridades que deben garantizar la protección de los derechos en juego.

\section{Un aspecto que cobra importancia: La privacidad en la relación cliente-abogado}

El último carácter que se analizará sobre la arbitrariedad en los procesos políticamente expuestos es el de la confidencialidad entre clientes y abogados.

A lo largo de este trabajo se ha notado como en los distintos sistemas de protección de derechos humanos, la imparcialidad del tribunal está prevista normativamente y brinda confianza a los distintos actores de un proceso. Esta confianza es crucial para la legitimidad del sistema de justicia. Sin embargo, se rompe en el caso 
de juzgamiento de figuras políticas cuando se percibe que los tribunales actúan de forma parcial o irregular.

El avance de las telecomunicaciones ha resaltado la relevancia de una garantía específica de sumo interés en los procesos políticamente expuestos: el derecho a la confidencialidad de las comunicaciones que tiene quien está sometido a proceso con su abogado. La facilidad con la Estados y empresas tienen acceso a las comunicaciones por teléfono, correo o servicios de mensajería como WhatsApp vuelve urgente analizar esta cuestión. Al tiempo de la redacción de los tratados, la vulneración de la privacidad de la comunicación entre un abogado y su cliente era el fruto de medidas directas. Hoy, la intervención de correos, teléfonos y servicios de mensajería, con la masividad e inmediatez que la tecnología permite, presenta desafíos distintos.

El derecho a la confidencialidad en la comunicación entre un acusado y su abogado surge en el common lawen el siglo XVI (Dawson Jr. et al., 1985, 560). La protección se vinculó desde temprano al rol del abogado: solo de esa manera podría dar un asesoramiento y defensa acorde a las necesidades de sus clientes. A la vez, servía al acusado pues "si no existiera [este privilegio], un hombre no se animaría a consultar a una persona capaz, o le diría solo la mitad de su caso"67.

La protección de la confidencialidad en esta especie concreta de comunicaciones es la consecuencia necesaria de la tutela de dos derechos que funcionan como marco básico: el derecho a las garantías judiciales y el derecho a la privacidad. El derecho a la privacidad facilita, entre otros aspectos de la vida, las comunicaciones con personas con los que se busca cierta intimidad — como puede ser un médico, un sacerdote 0 , precisamente, un abogado—68. Las garantías judiciales tienen por objeto que toda persona goce de un

\footnotetext{
${ }^{67}$ Suprema Corte de Justicia de Virginia, Estados Unidos, Chahoon v. Commonwealth, 62 Va. (21 Gratt.) 838 (1871).

${ }^{68}$ Corte IDH, Caso De La Cruz Flores vs. Perú, Fondo, Reparaciones y Costas, Sentencia de 18 de noviembre de 2004, Serie C No. 115, voto razonado del Juez Sergio García Ramírez, párr. 8.
} 
proceso con ciertos recaudos mínimos, entre las que "dirigirse a su abogado sin temor a que la información confidencial que le comunique pueda ser ulteriormente divulgada" ${ }^{69}$ es una de ellas.

En definitiva, la idea de un proceso judicial técnico solo puede funcionar de manera justa si quien se encuentra acusado tiene a su favor ciertas garantías básicas: no está obligado a declarar en su contra, puede contar con un traductor, puede recurrir la decisión que no lo favorece, puede presentar prueba y analizar la evidencia (Convención Americana de Derechos Humanos, artículo 8). Ahora bien, sin un abogado que lo asista en firma libre y confidencial, todas estas medidas caen en saco roto.

\section{El derecho internacional y la protección de la confidencialidad de la relación entre el abogado y el cliente}

El derecho internacional de los derechos humanos ha consagrado la protección de la relación confidencial entre el abogado y su cliente en diversos tratados. También el soft law ha desarrollado estándares de privacidad de esta relación.

La Convención Americana, en su artículo 8, protege diversas garantías judiciales. Más precisamente, el artículo 8 expresa: “2. Toda persona inculpada de delito tiene derecho a que se presuma su inocencia mientras no se establezca legalmente su culpabilidad. Durante el proceso, toda persona tiene derecho, en plena igualdad, a las siguientes garantías mínimas: (...) d) derecho del inculpado de defenderse personalmente o de ser asistido por un defensor de su elección y de comunicarse libre y privadamente con su defensor". Este artículo tiene el serio riesgo de convertirse en letra muerta si no es custodiado por el abogado en cada situación concreta. Y en todo

\footnotetext{
69 Corte de Justicia de la Unión Europea, 2007 II-03523, Asuntos acumulados T-125/03 y T-253/03, Akzo Nobel Chemicals Ltd y Akcros Chemicals Ltd contra Comisión de las Comunidades Europeas, 17 de septiembre de 2007.
} 
caso, la comunicación libre y privada es fundamental para perfeccionar el ejercicio del derecho.

En forma algo más genérica, el Pacto Internacional por los Derechos Civiles y Políticos establece en su artículo 14: "Durante el proceso, toda persona acusada de un delito tendrá derecho, en plena igualdad, a las siguientes garantías mínimas: b) A disponer del tiempo y de los medios adecuados para la preparación de su defensa y a comunicarse con un defensor de su elección”. Esta comunicación es confidencial, y así lo ha reconocido la jurisprudencia del Comité de Derechos Humanos.

También existen normas de soft law al respecto. Los Principios Básicos sobre la Función de los Abogados (1990) protegen el derecho a la asistencia de un abogado en diversos términos. En asuntos penales, sostiene: "8. A toda persona arrestada, detenida, o presa, se le facilitarán oportunidades, tiempo e instalaciones adecuadas para recibir visitas de un abogado, entrevistarse con él y consultarle, sin demora, interferencia ni censura y en forma plenamente confidencial. Estas consultas podrán ser vigiladas visualmente por un funcionario encargado de hacer cumplir la ley, pero no se escuchará la conversación".

A la vez, se le garantiza a los abogados que puedan "viajar y comunicarse libremente con sus clientes tanto dentro de su país como en el exterior". Por último, se entiende que "[l]os gobiernos reconocerán y respetarán la confidencialidad de todas las comunicaciones y consultas entre los abogados y sus clientes, en el marco de su relación profesional" (Principio 16 b).

\section{La jurisprudencia internacional en torno de la garantía de confidencialidad}

La jurisprudencia del derecho internacional de los derechos humanos, e incluso del derecho internacional público, ha sido clara al resguardar el principio de confidencialidad en la relación entre 
abogados y sus clientes. Posiblemente sea en el sistema europeo de derechos humanos donde más se ha desarrollado esta protección en buena medida por ser el tribunal regional con más casos-. Pero el Comité de Derechos Humanos de Naciones Unidas, el Sistema Interamericano de Derechos Humanos, e incluso la Corte Internacional de Justicia, también se han pronunciado al respecto.

Este consenso regional evidencia que la confidencialidad en la comunicación entre cliente y abogado es un principio general del derecho, según lo dispone el artículo 38 del Estatuto de la Corte Internacional de Justicia.

\section{a. Sistema Interamericano de Derechos Humanos}

El Sistema Interamericano de Derechos Humanos, compuesto por la Comisión y la Corte Interamericana, tiene una creciente influencia en los países que componen la Organización de Estados Americanos. Su jurisprudencia es determinante en diversos países del continente. En este sistema regional, existen diversos casos y reportes que influyen en el entendimiento del marco para entender el problema.

La confidencialidad para la Comisión Interamericana de Derechos Humanos

Los organismos del Sistema Interamericano tienen diversas formas de actuación. La Comisión actúa a través de casos, pero tiene un mandato de promoción que le da cierta flexibilidad. Bajo esta amplitud, emite informes temáticos, de país, dicta comunicados de prensa o requerimientos de información (Boulin Victoria 2016, 26).

En el año 1999, la CIDH señaló el problema de la falta de confidencialidad en la relación de abogado y acusado en Colombia, en su informe anual. En el contexto del conflicto armado, con permanentes hechos de violencia contra jueces y abogados, surgió la 
denominada "justicia regional". Esta buscaba reservar la identidad de los jueces para resguardar sus vidas (El Tiempo, 1997).

Sin embargo, para la Comisión, la actuación de la justicia no puede impedir la comunicación libre y fluida entre el abogado y su cliente (CIDH, 1999). Así, expresaba:

\begin{abstract}
115. Otra denuncia frecuente recibida por la Comisión en relación con el sistema de justicia regional se refiere al derecho del inculpado a la asistencia de un abogado. De acuerdo con estas denuncias, con frecuencia se imponen restricciones en el sistema de justicia regional para dificultar la comunicación en privado del inculpado con su abogado. La Comisión considera que estas limitaciones constituyen una violación flagrante del derecho del acusado "a comunicarse libre y privadamente con su asesor", protegido por el artículo 8(2)(d) de la Convención Americana.
\end{abstract}

La relevancia de este principio ha sido marcada por la Comisión en momentos de suma complejidad. En el año 2002, luego de los atentados terroristas en Estados Unidos, la Comisión Interamericana emitió un informe temático sobre Terrorismo y Derechos Humanos. El respaldo a la confidencialidad entre abogado y cliente fue notorio. Para la CIDH, sin esta garantía no puede asegurarse un juicio justo y eso es algo que debe asegurarse a toda persona:

El derecho a la asistencia de un abogado está a su vez íntimamente relacionado con el derecho del acusado a disponer de tiempo y medios suficientes para la preparación de su defensa, lo que requiere que todos los arrestados, detenidos o encarcelados dispongan de oportunidades, tiempo y facilidades adecuadas para ser visitados y para comunicarse y consultar a su abogado, sin demora, intercepción o censura y con total confidencialidad (párr. 237).

La mención a la "total confidencialidad" y la prohibición de la censura e intercepción son estándares de fuerte peso: no se admite 
ninguna restricción para el resguardo de confidencialidad con los abogados.

La Comisión volvió a referirse a este tema al publicar un informe sobre los problemas de los detenidos en Guantánamo (CIDH, 2015). En este reporte, la CIDH expresó que "[e]l derecho al tiempo y las condiciones adecuadas para preparar la defensa es uno de los componentes básicos del derecho a un juicio justo cuya suspensión no puede justificarse"70. La garantía, para la CIDH, es inderogable. Por eso, resaltó

la falta de respeto a los privilegios entre abogado y cliente en la Bahía de Guantánamo. Las autoridades del centro de detención tienen acceso a correos privados con la representación jurídica, se prohíbe ciertos temas de conversación entre los abogados defensores y sus clientes, y los abogados defensores militares no pueden tener conversaciones telefónicas con sus representados. Más aún, la CIDH manifiesta su gran preocupación por el hecho de que reglas estrictas sobre la información clasificada podrían llevar a la acusación a retener prueba clave, y que reglas irrazonables sobre la información clasificada trasladen a la defensa la carga de demostrar que la prueba puede ser producida. Con base en los estándares mencionados anteriormente, estas restricciones claramente constituyen una violación al derecho a una defensa adecuada. A su vez, esto no sólo afecta la confianza de los detenidos en las comisiones militares, sino también la confianza del público en el sistema ${ }^{71}$.

Puede concluirse que la Comisión ha sido enfática al vincular la importancia de la confidencialidad en la relación del abogado y el cliente para la defensa en juicio. La confidencialidad es protegida en

\footnotetext{
${ }^{70} \mathrm{CIDH}$, Hacia el cierre de Guantánamo, OEA/Ser.L/V/II., Doc. 20/15, 3 Junio 2015, párr. 249.

${ }^{71}$ Ibídem, párr. 250.
} 
forma completa, durante el tiempo suficiente, sin intercepciones o censuras, y de manera inderogable.

La confidencialidad en la jurisprudencia de la Corte IDH: El caso Suárez Rosero

La Corte Interamericana también ha sido terminante al momento de proteger la confidencialidad entre el acusado y su abogado. El primer caso en el que la Corte IDH se expidió sobre el tema fue Suárez Rosero.

En 1992 la Policía Nacional de Ecuador detuvo al señor Suárez Rosero, sin orden judicial y sin ser sorprendido en flagrancia, en el marco de una operación que investigaba una organización de narcotráfico. Suárez Rosero fue incomunicado durante 36 días desde el momento inicial de su aprehensión. Entre diversas violaciones al debido proceso, la Corte Interamericana entendió que la incomunicación vulneró su derecho a comunicarse en forma libre y privada con su abogado defensor ${ }^{72}$.

Como puede notarse, la Corte no solo declaró una violación a la genérica, sino que equiparó la falta de comunicación a la comunicación que no es libre o privada con el letrado.

\section{La decisión de la Corte IDH en el caso Castillo Petruzzi}

El caso Castillo Petruzzi también vincula de forma clara el derecho al debido proceso con la garantía de la privacidad de las comunicaciones entre un abogado y su defendido ${ }^{73}$.

Los hechos transcurrieron en Perú, en medio de un conflicto entre las Fuerzas Armadas y grupos armados. En 1993 fueron

\footnotetext{
72 Corte IDH, Caso Suárez Rosero v. Ecuador, Sentencia de 12 de noviembre de 1977 (Fondo), Serie C No. 35.

73 Corte IDH, Caso Castillo Petruzzi y otros vs. Perú, Fondo, Reparaciones y Costas, Sentencia de 30 de mayo de 1999, Serie C No. 52.
} 
detenidos cuatro nacionales chilenos. Fueron juzgados por jueces sin rostro y no pudieron comunicarse de manera confidencial con sus abogados.

La Corte IDH fue consistente con el precedente Suárez Rosero y sostuvo que cuando los "abogados defensores tuvieron obstáculos para entrevistarse privadamente con sus defendidos, la Corte ha declarado que hay violación del artículo 8.2.d de la Convención”74.

\section{La confidencialidad y el derecho al honor: El caso Tristán Donoso}

En el caso Tristán Donoso ${ }^{75}$, el eje gira hacia el artículo 11 de la Convención Americana, que protege el derecho a la vida privada ${ }^{76}$. Tristán Donoso era abogado y fue grabado telefónicamente hablando con un defendido, como parte de una investigación que desarrollaba el Ministerio Público por lavado de dinero. En lo que aquí importa, la Corte estableció primero que las comunicaciones telefónicas eran una "forma de comunicación que, al igual que la correspondencia, se encuentra incluida dentro del ámbito de protección del derecho a la vida privada"77.

Ahora bien, la comunicación entre Tristán Donoso y un cliente gozaba de una protección mayor aún, pues se vinculaba con el secreto profesional $^{78}$.

\footnotetext{
${ }^{74}$ Ibídem, párr. 148, citando el caso Suárez Rosero c. Ecuador.

75 Corte IDH, Caso Tristán Donoso vs. Panamá, Excepción preliminar, Fondo, Reparaciones y Costas, Sentencia del 27 de enero de 2009, Serie C No 193.

${ }^{76}$ Convención Americana de Derechos Humanos, art. 11: "Protección de la Honra y de la Dignidad. 1. Toda persona tiene derecho al respeto de su honra y al reconocimiento de su dignidad. 2. Nadie puede ser objeto de injerencias arbitrarias o abusivas en su vida privada, en la de su familia, en su domicilio o en su correspondencia, ni de ataques ilegales a su honra o reputación. 3. Toda persona tiene derecho a la protección de la ley contra esas injerencias o esos ataques".

77 Corte IDH, Caso Tristán Donoso vs. Panamá, op. cit., párr. 55.

${ }^{78}$ Entiende la Corte que "la conversación telefónica entre el señor Adel Zayed y el señor Tristán Donoso era de carácter privado y ninguna de las dos personas consintió que fuera conocida por terceros. Más aún, dicha conversación, al ser realizada entre la presunta víctima y uno de sus clientes debería, incluso, contar con un mayor grado de
} 


\section{b. Sistema Europeo de Derechos Humanos}

El sistema europeo también recoge una fuerte custodia de la confidencialidad en la comunicación de abogados con sus clientes (Giraudeau, 2016). Este derecho incluye el derecho a que no se interfiera en la comunicación entre los clientes y sus asesores, y el derecho a la confidencialidad de esas comunicaciones (Ibid.).

El principio es claro y tolera pocas excepciones. Para la Corte Europea, "es uno de los principios fundamentales en los que la administración de justicia en una sociedad democrática está basada"79.

A diferencia de lo que ocurre en el Sistema Interamericano, el tratado europeo no explicita la protección de la comunicación privada entre el abogado y su cliente. Por ello, la Corte Europea trata el tema como una extensión del derecho a la privacidad que impacta en la protección de las garantías judiciales.

[L]a confidencialidad de toda la "correspondencia" entre particulares, ofrece una protección reforzada a los intercambios entre los abogados y sus clientes. Esto se justifica por el hecho de que los abogados tienen asignado un papel fundamental en una sociedad democrática, el de defender a los litigantes. (...)[L]os abogados no pueden llevar a cabo esta tarea esencial si no pueden garantizar a sus defendidos que sus intercambios serán confidenciales. Lo que está en juego es la relación de confianza entre ellos, esencial para el cumplimiento de esa misión. De forma indirecta, pero necesariamente dependiente, está el derecho de toda persona a un juicio justo, incluido el derecho de los acusados a no autoinculparse ${ }^{80}$.

protección por el secreto profesional”. Corte IDH, Caso Tristán Donoso vs. Panamá, op. cit., párr. 75.

${ }^{79}$ TEDH, Michaud v. Francia, aplicación no. 12323/11, sentencia del 6 de diciembre de 2012.

${ }^{80}$ Ibídem, párr. 118. 
La sentencia dictada en Kopp vs. Suiza ${ }^{81}$ resulta de interés para entender la concepción europea. En este caso se estaban monitoreando las líneas telefónicas de una firma de abogados en el marco de un procedimiento penal que investigaba a un tercero. El Tribunal Europeo declaró que este monitoreo implicaba una violación al artículo 8 del Convenio Europeo, pues la legislación suiza no era clara ni precisa. Al contrario, dejaba un gran margen a la discrecionalidad de la autoridad. Más aún, en la práctica esto ocurría sin supervisión de un juez, sino directamente por un funcionario ejecutivo. Esto era especialmente grave en un tema sensible, como las relaciones entre un abogado y sus clientes, pues afectaba el derecho de defensa.

Según la jurisprudencia del tribunal europeo, solo en ciertas excepciones puede romperse la privacidad en las comunicaciones entre el abogado y su cliente. En primer lugar, deben cumplirse los recaudos habituales para las restricciones de derechos: a) la base normativa; b) el interés legítimo perseguido; c) la proporcionalidad de la restricción. En segundo lugar, el producto de la intercepción al abogado es permisible si es quien comete el delito, pero solo puede ser incorporada al expediente si no afecta el derecho de defensa del cliente $^{82}$.

\section{c. Sistema Universal de Derechos Humanos}

El sistema universal de derechos humanos también protege el derecho de toda persona sujeta a un proceso judicial a comunicarse privadamente con su abogado.

\footnotetext{
${ }^{81}$ TEDH, Kopp v. Suiza, aplicación no. 23224/94, sentencia del 25 de marzo de 1998.

${ }^{82}$ En el Caso Versini-Campinchi et Crasnianski v. France, la Corte entendió que la escucha telefónica ordenada por un juez a un acusado de un delito podían ser incorporadas al expediente si el abogado está participando de un delito. Pero, a la vez, la Corte entendió que esta interpretación debía ser restrictiva, y que no se podía usar en contra del cliente del abogado. TEDH, Versini-Campinchi y Crasnianski v. Francia, application no. 49176/11, sentencia del 16 de junio de 2016.
} 
El Grupo de Trabajo sobre Detención Arbitraria también ha manifestado preocupación por normas legales que permiten que autoridades carcelarias supervisen la comunicación entre un abogado sospechado de ser miembro de una organización terrorista y su cliente son contrarias (Comité de Derechos Humanos de Naciones Unidas 2007).

Por su parte, el Relator Especial para la Independencia de Jueces y Abogados también ha señalado que este derecho debe ser protegido en forma estricta. En 2009 indicó en un informe ante el Consejo de Derechos Humanos (Relatoría Especial para la Independencia de Magistrados y Abogados, 2009):

Uno de los principios fundamentales para el funcionamiento de los abogados se relaciona con la relación confidencial entre el abogado y el cliente. Sobre este punto, el principio 22 de los Principios Básicos estipula que "Los gobiernos reconocerán y respetarán la confidencialidad de todas las comunicaciones y consultas entre los abogados y sus clientes, en el marco de su relación profesional". Este principio adquiere una importancia aún mayor cuando el cliente del abogado está privado de libertad (párr. 44).

El Relator Especial también ha remitido comunicaciones criticando un proyecto de ley que obligaba a "a los abogados a suministrar sus archivos de trabajo como parte de una posible indagación" (Ibid., párr. 45). Más aún, ha marcado en forma crítica cuando las conversaciones entre abogados y clientes son escuchadas o grabadas (Ibid., párr. 46).

El Comité, por su parte, ha señalado en sus observaciones, y ha condenado en casos individuales, que cuando la privacidad no es respetada en este tipo de comunicaciones se configura una violación del artículo 14 del PIDCP.

En su observación general 32, el Comité de Derechos Humanos de Naciones Unidas estableció: 
El derecho a comunicarse con el defensor exige que se garantice al acusado el pronto acceso a su abogado. Los abogados deben poder reunirse con sus clientes en privado y comunicarse con los acusados en condiciones que garanticen plenamente el carácter confidencial de sus comunicaciones (párr. 34).

Esta observación ofrece la guía para comprender la manera en la cual este derecho es protegido en el sistema de Naciones Unidas. La comunicación con el abogado defensor debe ser pronta, privada y confidencial.

El Comité de Naciones Unidas también ha tenido la oportunidad de pronunciarse en casos resueltos a partir del protocolo facultativo. En numerosas decisiones ha declarado que las reuniones entre un acusado y su abogado no puede ser frente a los investigadores:

6.4. El Comité ha observado las reclamaciones de la autora de que su hijo estuvo representado legalmente sólo un mes después de haber sido acusado de varios delitos y de que todos los encuentros entre él y el abogado que la instrucción le asignó posteriormente tuvieron lugar en presencia de un investigador, en contravención del apartado b) del párrafo 3 del artículo 14. El Comité considera que los alegatos de la autora relativos al momento y las condiciones en los que su hijo fue asistido por un abogado afectaron a las posibilidades del hijo de la autora para preparar su defensa. A falta de cualesquiera explicaciones del Estado Parte, el Comité considera que los hechos que examina revelan una violación de los derechos del Sr. Khomidov a tenor del apartado b) del párrafo 3 del artículo 14 del Pacto (Comité de Derechos Humanos, 2002, párr. 15).

El párrafo citado contiene un patrón se repite en otras comunicaciones (Comité de Derechos Humanos, 2000).

Como puede notarse, el sistema de ONU protege a través de sus organismos y procedimientos especiales en forma rotunda la 
privacidad entre abogados y sus clientes, como parte sustancial del derecho al juicio justo.

\section{d. La confidencialidad como principio general del derecho. La jurisprudencia de la Corte Internacional de Justicia}

La Corte Internacional de Justicia también ha protegido este derecho. Esta tutela es especialmente relevante, pues coloca esta garantía como un principio general del derecho según el artículo 38 del Estatuto de la Corte Internacional de Justicia ${ }^{83}$.

En el caso Questions Relating to the Seizure and Detention of Certain Documents and Data (Timor-Leste v. Australia), la Corte entendió que un Estado tiene "el derecho a llevar a cabo procedimientos de arbitraje o negociaciones sin interferencia por parte de Australia, incluyendo el derecho de confidencialidad y no interferencia en sus comunicaciones con sus asesores legales" ${ }^{84}$. La Corte derivó este derecho del principio de igualdad soberana de los Estados. La igualdad de las partes que están en un procedimiento judicial —o en un proceso de solución amistosa, como en este casosupone para las partes una expectativa "de llevar los procedimientos de arbitraje o las negociaciones sin interferencia de la contraparte en la preparación y conducción del caso. Se seguiría de aquí que, en tal situación, un derecho plausible a la protección de sus comunicaciones con su abogado en lo relativo al arbitraje y las

\footnotetext{
83 El artículo 38 expresa: “1. La Corte, cuya función es decidir conforme al derecho internacional las controversias que le sean sometidas, deberá aplicar: a. las convenciones internacionales, sean generales o particulares, que establecen reglas expresamente reconocidas por los Estados litigantes; b. la costumbre internacional como prueba de una práctica generalmente aceptada como derecho; c. los principios generales de derecho reconocidos por las naciones civilizadas; d. las decisiones judiciales y las doctrinas de los publicistas de mayor competencia de las distintas naciones, como medio auxiliar para la determinación de las reglas de derecho, sin perjuicio de lo dispuesto en el Artículo 59. 2. La presente disposición no restringe la facultad de la Corte para decidir un litigio ex aequo et bono, si las partes así lo convinieren".

${ }^{84}$ Questions relating to the Seizure and Detention of Certain Documents and Data (Timor-Leste v. Australia), Provisional Measures, Order of 3 March 2014, I.C.J. Reports 2014, p. 147, párr. 27 (la traducción es propia).
} 
negociaciones, así como a la protección de la confidencialidad de todo cualquier documentos y datos preparados por el abogado para aconsejar al Estado en tal contexto" ${ }^{85}$.

\section{La confidencialidad de las conversaciones entre abogado-cliente no puede ser derogada en un estado de excepción}

La confidencialidad de las comunicaciones entre abogado y cliente merecen una especial protección, más aún si se desarrollan en el marco de un proceso penal. Al ser una derivación del debido proceso legal, resulta tan esencial que en el ámbito interamericano de protección de los derechos humanos se establece la prohibición de suspenderla aún en contextos de emergencia.

El artículo 27 de la Convención Americana admite que en caso de guerra, peligro público $u$ otra emergencia que amenace la independencia o seguridad de un Estado, éste pueda suspender el ejercicio de determinados derechos, en la medida y por el tiempo estrictamente necesario conforme a las exigencias de la situación (inciso 1). Sin embargo, la misma disposición prohíbe expresamente la suspensión de las garantías judiciales indispensables para la protección de ciertos derechos: a la vida, a la integridad personal, a la legalidad, al reconocimiento de la personalidad jurídica; a la prohibición de la esclavitud y servidumbre, a la libertad de conciencia y de religión, a la protección a la familia, al nombre, a la nacionalidad, los derechos políticos y los derechos del niño (inciso 2).

La prohibición de suspensión de las garantías judiciales se funda en la necesidad de que incluso en los estados de excepción existan formas de garantizar los derechos cuando se ven amenazados o vulnerados. Habilitar en emergencia la suspensión de las garantías judiciales supondría vaciar de contenido real a los derechos, pues

${ }^{85}$ Ibídem. 
todo quedaría a merced de la autoridad (Corte IDH, OC-9/87 1987, párrafo 21).

Al interpretar el artículo 27 (Ibid., párr. 22), la Corte IDH ha dejado en claro que deben considerarse como garantías judiciales indispensables no susceptibles de suspensión, por un lado, los recursos efectivos ante los jueces o tribunales competentes (artículo 25 de la $\mathrm{CADH}$ ), destinados a garantizar el respeto a los derechos y libertades cuya suspensión no está autorizada por la misma Convención. También deben considerarse como garantías judiciales indispensables que no pueden suspenderse, aquellos procedimientos judiciales previstos en el derecho interno de los Estados Partes como idóneos para garantizar la plenitud del ejercicio de los derechos establecidos en el artículo 27.2 de la Convención y cuya supresión o limitación comporte la indefensión de tales derechos. Las garantías judiciales mencionadas deben ejercitarse dentro del marco y según los principios del debido proceso legal, recogidos por el artículo 8 de la Convención. Es decir, en los recursos y los procedimientos judiciales destinados a tutelar los derechos establecidos en el artículo 27 deben respetarse las garantías del debido proceso del artículo 8.

Dicha norma reconoce el debido proceso legal, que abarca las condiciones que deben cumplirse para asegurar la adecuada defensa de aquéllos cuyos derechos u obligaciones están bajo consideración judicial. Es decir, establece el conjunto de requisitos que deben observarse en las instancias procesales para que pueda hablarse de verdaderas y propias garantías judiciales según la Convención. Los principios del debido proceso legal no pueden suspenderse con motivo de las situaciones de excepción en cuanto constituyen condiciones necesarias para que los instrumentos procesales, regulados por la Convención, puedan considerarse como garantías judiciales.

Por lo tanto, entre las "condiciones" no susceptibles de suspensión se encuentra el "derecho del inculpado de defenderse 
personalmente o de ser asistido por un defensor de su elección y de comunicarse libre y privadamente con su defensor".

En conclusión, el debido proceso legal exige que el inculpado tenga el derecho de acceder a un abogado y pueda comunicarse con él de forma privada y este derecho no puede suspenderse en contextos de emergencia. Menos aún podrá suspenderse en situación de normalidad.

En condiciones normales, la inexistencia de recursos efectivos contra las violaciones a los derechos humanos y la inobservancia de las garantías judiciales reconocidas en el artículo 8.1 de la Convención constituyen una transgresión de la misma. Pero aun cuando se implante un estado de emergencia, en palabras de la propia Corte IDH, este "no puede comportar la supresión o la perdida de efectividad de las garantías judiciales que los Estados Partes están obligados a establecer, según la misma Convención, para la protección de los derechos no susceptibles de suspensión o de los no suspendidos en virtud del estado de emergencia” (Ibid., párr. 25).

Dentro de estas se encuentra la garantía del inculpado a ser asistido por un abogado defensor y de comunicarse libre $y$ privadamente con él.

\section{Laboratorio de pruebas: distintos ejemplos sobre actuaciones de tribunales que perjudican la confianza en el sistema}

Hasta aquí se ha realizado un análisis teórico de ciertas facetas que deben ser especialmente cuidadas en los procesos políticamente expuestos. En este apartado se brindarán ejemplos que ilustran lo visto. 


\section{a. Casos de figuras políticas sustraídas de sus tribunales de origen o juzgadas por jueces incompetentes}

La actuación indebida de los jueces, ya sea por intervenir en procesos que no debían originalmente conocer o por su falta de competencia, merma la credibilidad de cualquier decisión judicial que se adopte.

En Honduras, la actuación de la Corte Suprema de Justicia fue objeto de fuertes cuestionamientos por falta de imparcialidad en casos por corrupción seguidos contra el expresidente Rafael Leonardo Callejas. El máximo tribunal confirmó las actuaciones de la juez Mildra Castillo que, a pesar de ser incompetente ${ }^{86}$, conoció y decretó la libertad de Callejas por falta de méritos en una serie de procesos seguidos contra el ex mandatario por los delitos de abuso de autoridad, falsificación de documentos y malversación de fondos públicos (La Prensa, 2007). El escándalo fue tal que siete de los magistrados de la Corte Suprema de Justicia ${ }^{87}$ emitieron un comunicado señalando que se vieron obligados a emitir un voto particular al estar en desacuerdo con que una jueza incompetente conociera de estos casos, ya que ello violaba el artículo 90 de la Constitución Política de la República (Ibid.).

Recientemente, en Brasil, el Juez de la Corte Suprema de Justicia Edson Fachin, determinó que el Juez Sergio Moro, titular del tribunal de primera instancia de Curitiba, que investigó el Lava Jatoy condenó a Luiz Inácio da Silva, no tenía competencia para juzgar al expresidente y anuló cuatro procesos ${ }^{88}$. La decisión fue confirmada

\footnotetext{
${ }^{86}$ Según el Ministerio Público Fiscal, cuando Callejas fue procesado era diputado al Parlamento Centroamericano, por lo que gozaba de inmunidad y debía ser juzgado por uno de los quince magistrados de la Corte Suprema de Justicia y no por una jueza de primera instancia como Mildra Castillo.

${ }^{87}$ Los magistrados fueron Marco Tulio Barahona, Carlos Alberto Gómez Moreno, Daisy Rodríguez Rodríguez, Marta Castro Roque, Sonia Marlina Dubón Villeda, Héctor Efraín Fortín Villeda.

${ }^{88}$ El Juez Fachin estableció la incompetencia del juez Sérgio Moro y del Juzgado 13 de la Subsección judicial de Curitiba para procesar y juzgar las acciones penales 504651294.2016.4.04.7000/PR (triplex en la ciudad balnearia de Guarujá, en la costa paulista), 5021365- 32.2017.4.04.7000/PR (terreno en Atibaia, localidad también paulista), 5063130-17.2018.4.04.7000/PR (sede del Instituto Lula) y 5044305-
} 
por el pleno de la Corte Suprema de Justicia el pasado 22 de abril ${ }^{89}$. De esta forma, el máximo tribunal del país reconoció que Lula fue sustraído de su juez competente, es decir, del tribunal originalmente llamado para investigarlo por presunta corrupción (que luego se determinó serían los tribunales de Brasilia) y anuló los procesos.

En Colombia ocurrió algo similar con el expresidente y exsenador Álvaro Uribe. Siendo senador nacional, Uribe fue investigado y procesado por presunta manipulación de testigos y fraude procesal por la Sala de Casación Penal de la Corte Suprema de Justicia (“SCP”) cuando esta no sería competente para ello. En virtud del Acto Legislativo No. 1 del 18 de enero de 2018, mediante el cual Colombia modificó su Constitución Política, se sustrajo la competencia a la Sala de Casación Penal para investigar y juzgar a los aforados constitucionales, esto es, aquellos funcionarios que tienen fueros en virtud de la Constitución Política, como sucede con los miembros del Senado y de la Cámara de Representantes ${ }^{90}$. La competencia para la "substanciación de cualquier acusación de carácter penal" sobre los congresistas fue acordada a la Sala Especial Instrucción Penal ${ }^{91}$. Sin

83.2020.4.04.7000/PR (donaciones al Instituto Lula). Superior Tribunal de Justicia, Ag. Reg. No habeas corpus 193.726 Paraná, Relator Min. Edson Fachin. Véase resolución en Resolución del Magistrado Edson Fachin, fecha 8 de marzo de 2021, disponible en http://www.stf.jus.br/arquivo/cms/noticiaNoticiaStf/anexo/HC193726AgReAgRnoAg RVotoMGM.pdf (última visita el 31 de mayo de 2021).

${ }^{89}$ Véase resolución del Supremo Tribunal Federal de fecha 22 de abril de 2021 en el caso "Reg. No Habeas Corpus 193.726 Paraná", votos de los ministros Gilmar Mendes, Nunes Marques, Alexandre de Moraes, Dias Toffoli y Ricardo Lewandowski, y los ministros Rosa Weber y Cármen Lúcia, disponible en http://portal.stf.jus.br/noticias/verNoticiaDetalhe. asp?idConteudo=464602\&ori=1 (última vista el 27 de mayo de 2021).

${ }^{90}$ En Colombia, son aforados constitucionales los funcionarios que tienen fueros en virtud de la Constitución Política, como sucede con los Senadores y Representantes a la Cámara y los demás funcionarios a que se refieren los artículos 174, y 235 numerales 2 y 4 de la Constitución Política del país. Al respecto, véase la Sentencia C-934/06 de la Corte Constitucional de Colombia de fecha 15 de noviembre de 2006.

91 El Artículo 186 dispone: "De los delitos que cometan los Congresistas, conocerá en forma privativa la Corte Suprema de Justicia, única autoridad que podrá ordenar su detención. En caso de flagrante delito deberán ser aprehendidos y puestos inmediatamente a disposición de la misma corporación. Corresponderá a la Sala Especial de Instrucción de la Sala Penal de la Corte Suprema de Justicia investigar y acusar ante la Sala Especial de Primera Instancia de la misma Sala Penal a los miembros del Congreso por los delitos cometidos. Contra las sentencias que profiera la Sala Especial de Primera Instancia de la Sala Penal de la Corte Suprema de Justicia procederá 
embargo, el 16 de febrero y el 22 de febrero de 2018, los magistrados de la SCP habrían ordenado investigar al entonces senador Uribe sin tener competencia para ello. Durante varios meses, habrían practicado pruebas y diligencias, incluyendo interceptaciones de comunicaciones entre Uribe y su abogado defensor ${ }^{92}$. El 17 de octubre de 2018, la SCP remitió el proceso a la Sala Especial de Instrucción. Dos años más tarde, el 4 de agosto de 2020, la Sala Especial de Instrucción ordenó la detención domiciliaria de Uribe y su sustitución por la detención domiciliaria ${ }^{93}$, presuntamente basado en pruebas recabadas por magistrados incompetentes.

La actuación indebida de los jueces que intervienen en estos procesos mina la confianza de la sociedad en los tribunales. Poco a poco, la Justicia pierde credibilidad y prestigio cuando los investigados son sustraídos de los jueces originalmente llamados a conocer las acusaciones en su contra. Los procesos políticamente expuestos — que llaman la atención preferente de la ciudadaníarequieren una intervención intachable de los jueces (Fundación para el Debido Proceso Legal 2007, 157).

el recurso de apelación. Su conocimiento corresponderá a la Sala de Casación Penal de la Corte Suprema de Justicia. La primera condena podrá ser impugnada”.

${ }^{92}$ Cfr. Corte Suprema de Justicia de Colombia, Sala Especial de Instrucción, Magistrado Ponente César Augusto Reyes Medina, decisión del 3 de agosto de 2020, Radicación No. 52.240, disponible en https://www.eltiempo.com/uploads/files/2020/08/08/decisionde-la-corte.pdf (última visita el 13 de julio de 2021). Según se indica en la pág. 537 de la resolución, "Como labores de investigación en auto del 16 de marzo de 2018, se ordenó interceptar por el término de 60 días el abonado telefónico de Diego Cadena (abogado defensor de Uribe) 3012796660". Véase, también, Boris Miranda, "Los polémicos elementos con los que la Corte Suprema de Colombia decidió procesar al expresidente Álvaro Uribe", fecha 26 de julio de 2018, disponible en https://www.bbc.com/mundo/noticias-america-latina-44971952 (última visita el 3 de mayo de 2021); BBC News Mundo, "Álvaro Uribe: Corte Suprema de Colombia ordena el arresto domiciliario del expresidente por 'riesgos de obstrucción a la justicia”, fecha 4 de agosto de 2020, disponible en https://www.bbc.com/mundo/noticias-americalatina-53604677 (última visita 27 de mayo de 2021).

93 Corte Suprema de Justicia de Colombia, Corte Suprema ordena detención domiciliaria del senador Álvaro Uribe, fecha 4 de agosto de 2021, disponible en https://cortesuprema.gov.co/corte/index.php/2020/08/04/corte-suprema-ordenadetencion-domiciliaria-del-senador-alvaro-uribe/ (última visita el 27 de mayo de 2021). 
La competencia del artículo 8 de la CADH, según lo ha entendido la propia Corte, se refiere a la garantía de ser juzgado por un órgano que "actúe en los términos del procedimiento legalmente previsto para el conocimiento y la resolución del caso que se le somete" ${ }^{\text {94. }}$.

\section{b. El problema de las "escuchas" en los casos de los ex Presidentes de Brasil, Argentina y Colombia}

En varios países de América Latina existen antecedentes de escuchas telefónicas ordenadas en el marco de investigaciones seguidas contra ex Presidentes, que luego son filtradas al público. La revelación de este tipo de intercepciones deslegitima la imparcialidad de los tribunales. El efecto sobre el sistema democrático es a todas luces negativo, pues los procesos judiciales pasan a ser parte del campo de batalla político. Así, deja de existir el espacio neutro en el que las disputas no se resuelven por alineación partidaria.

El caso de la ex mandataria argentina, Cristina Fernández de Kirchner

\section{El marco legal de las escuchas telefónicas en Argentina}

En Argentina, el Código Procesal Penal de la Nación permite a los jueces ordenar la intervención de comunicaciones telefónicas ${ }^{95}$. Éstos también pueden obtener los registros que existan de las

\footnotetext{
${ }_{94}$ Corte IDH, Caso del Tribunal Constitucional. Fondo, Reparaciones y Costas, op. cit., párr. 77.

${ }_{95}$ El artículo 236 del Código Procesal Penal de la Nación Argentina establece que "El juez podrá ordenar, mediante auto fundado, la intervención de comunicaciones telefónicas o cualquier otro medio de comunicación del imputado, para impedirlas o conocerlas. Bajo las mismas condiciones, el Juez podrá ordenar también la obtención de los registros que hubiere de las comunicaciones del imputado o de quienes se comunicaran con él. En las causas en que se investigue alguno de los delitos previstos en los artículos 142 bis y 170 del Código Penal de la Nación, o que tramiten en forma conexa con aquéllas, cuando existiese peligro en la demora, debidamente justificado, dichas facultades podrán ser ejercidas por el representante del Ministerio Público Fiscal, mediante auto fundado, con inmediata comunicación al Juez, quien deberá convalidarla en el término improrrogable de veinticuatro horas, bajo pena de nulidad del acto y consecuente ineficacia de la prueba introducida a partir de él”.
} 
comunicaciones telefónicas del imputado o de quienes se comunicaran con él ${ }^{96}$.

Para que la interferencia de comunicaciones privadas sea legal en Argentina debe ser ordenada por un juez competente, en el marco de una causa constituida legalmente, cumpliendo con los requisitos procesales y no exceder el plazo legal establecido.

La Ley de Inteligencia Nacional (ley 25.520) sostiene que las comunicaciones son inviolables en todo el ámbito de la República Argentina, "excepto cuando mediare orden o dispensa judicial en sentido contrario" (art. 5). La ley dispone que "cuando en el desarrollo de las actividades de inteligencia o contrainteligencia” deban realizarse interceptaciones o captaciones de comunicaciones privadas, la Secretaría de Inteligencia debe solicitar fundadamente autorización para ello al juez federal penal competente (art. 18). Esta autorización puede concederse por un plazo no mayor a 60 días, prorrogables por otros 60 días como máximo, cuando ello fuera imprescindible para completar una investigación en curso (art. 19).

Por otra parte, la Ley Nacional de Telecomunicaciones (ley 19.798, art. 45 ter) obliga a las empresas prestadoras de servicios de telecomunicaciones a registrar y sistematizar las comunicaciones para su consulta por parte del Poder Judicial o el Ministerio Público Fiscal. Esa información debe ser conservada por un plazo de diez años $^{97}$.

Actualmente, la interceptación y captación de las comunicaciones privadas se encuentra dentro de la órbita de la Corte Suprema de Justicia de la Nación, en virtud de un Decreto de Necesidad y Urgencia emitido en el año $2015^{98}$.

\footnotetext{
96 Ibídem.

${ }^{97}$ Estos plazos y obligaciones se incorporaron a la ley de telecomunicaciones en 2003, con la sanción de la Ley 25.873, que fue declarada inconstitucional por la Corte Suprema en 2009 en el fallo "Halabi.

98 Decreto de Necesidad y Urgencia Nro. 256/2015 del Poder Ejecutivo Nacional, "Transfiérase el Departamento de Interceptación y Captación de las Comunicaciones", de fecha 24 de diciembre de 2015.
} 


\section{La difusión de escuchas telefónicas que involucran a la expresidenta Cristina Fernández de Kirchner}

En el marco de una causa por el delito de encubrimiento en la que se encontraba imputado Oscar Parrilli, alto funcionario y ex Director de la Agencia Federal de Inteligencia, el Juez Federal Ariel Lijo ordenó la interceptación de la línea telefónica de Parrilli (Télam 2017). En el marco de dichas escuchas, se habrían grabado conversaciones que el imputado mantuvo con la exmandataria Cristina Fernandez de Kirchner. Estas escuchas fueron filtradas al público durante el proceso, y antes de que Parrilli fuera sobreseído (EI Perfil2019).

En efecto, en el año 2017, se difundió en los medios de comunicación un diálogo telefónico entre Parrilli y Cristina Fernández de Kirchner (“El audio de Cristina Kirchner a Parrilli” 2021) en el que conversaban sobre una entrevista que el exdirector General de Operaciones de la AFI, Antonio Stiuso, concedió al diario La Nación en julio de 2016. A raíz de declaraciones que la expresidenta realiza en el audio difundido, se habría iniciado una investigación judicial en su contra por presunto abuso de autoridad por el supuesto armado de causas contra el exespía Antonio Stiuso (Infobae2017).

La difusión de esta conversación generó controversias en torno a los motivos de su filtración y respecto de su legalidad. Hubo quienes cuestionaron que la intervención telefónica ocurrió casi un año después de ocurrido el delito que se investigaba en la causa y advirtieron que se trató de un caso de "espionaje político" (Página 12 2017). Parrilli denunció que se trató de un caso de espionaje político por parte del Poder Ejecutivo con el objetivo de perjudicar a la expresidenta en el marco de la causa por abuso de autoridad que se inició a partir de escuchas telefónicas.

En el año 2018, se filtraron nuevas conversaciones privadas entre Cristina Fernández de Kirchner y el Sr. Parrili, aunque éstas no contenían datos sobre la investigación en el marco de la cual se habría ordenado la interceptación telefónica de Parrilli (El tiempo 2018). 
Todas estas filtraciones ocurrieron a pesar de que habría existido una orden judicial para que el material fuera destruido (Política Argentina 2017).

En Argentina no hubo caso de escuchas entre la exmandataria y sus abogados. La situación no fue de tal gravedad. Sin embargo, la confianza en los tribunales quedó maltrecha.

El caso de las escuchas telefónicas al ex presidente de Brasil y sus abogados

\section{El marco legal de las escuchas telefónicas en Brasil}

La Constitución de Brasil establece que "es inviolable el secreto de la correspondencia y las comunicaciones, salvo medida adoptada por orden judicial en las hipótesis y en la forma en que la ley establezca para fines de investigación criminal o instrucción procesal penal" (Art. 5. Inc. XII).

La Ley de Interceptación Telefónica (9.296/96) que reglamenta el inciso XII, parte final, del artículo $5^{\circ}$ de la Constitución Federal determina las hipótesis y los requisitos que deben ser observados en un procedimiento de interceptación telefónica con el fin de investigación criminal o instrucción penal. El artículo 10 de la mencionada norma establece que la interceptación telefónica requiere de autorización judicial y que la decisión judicial que la autoriza debe ser fundada y establecer el plazo por el cual se llevará a cabo la diligencia.

A su vez, la Ley 12.850/13 sobre organizaciones criminales exige a las compañías telefónicas retener datos sobre conversaciones telefónicas por cinco años, para llevar a cabo tareas de investigación y acusación. 


\section{La interceptación de las comunicaciones de Lula y sus abogados en el marco de la investigación por la causa Lava Jato}

En el marco de la causa seguida contra el exmandatario Luiz Inácio da Silva por presunto pago de sobornos y corrupción en la petrolera estatal Petrobras, el Juez federal Sergio Moro habría ordenado la interceptación de la línea telefónica no sólo de Lula, sino también del estudio jurídico "Teixeira Martins \& Asociados", encargado de su defensa en el juicio (Notiamerica, 2016).

Se trataría de 14 horas de conversaciones entre Lula y sus abogados Cristiano Zanin, Roberto Teixeira y Nilo Batista, relacionadas con estrategias para la defensa ante las acusaciones por corrupción. Estas conversaciones habrían sido utilizadas como informes en la causa por la cual fue condenado inicialmente a 12 años y un mes de cárcel (López Girondo, 2019).

La defensa de Lula, junto con la Orden de Abogados de Brasil, cuestionó duramente la legalidad de la interceptación de estas comunicaciones por entender que se afectó la garantía de confidencialidad cliente-abogado, ya que la legislación solo permite la interceptación de comunicaciones de personas que están siendo investigadas, y no era el caso de los defensores del ex presidente. En esta línea, la defensa de Lula advirtió que era "evidente que la finalidad (de la medida ordenada por el Juez Moro) era vigilar la estrategia de defensa del ex presidente configurando un grave atentado a las garantías constitucionales de inviolabilidad de las comunicaciones y defensa". A raíz de ello, Lula solicitó al Tribunal Supremo que investigue al Juez Moro por ordenar escuchas por motivos no previstos por la ley (Notiamerica, 2016).

Estas comunicaciones no fueron filtradas a la prensa. Sin embargo, sí hubieron casos en los cuales las conversaciones interceptadas del expresidente de Brasil fueron puestas en conocimiento del público, cuando debían permanecer bajo secreto judicial. 


\section{La filtración de escuchas entre Lula y Rousseff por el mismo Juez que las ordenó}

En el año 2016, se difundió en los medios de comunicación una conversación entre la entonces presidenta Dilma Rousseff y su antecesor, Luiz Inácio Lula da Silva (Lissardy, 2016). La conversación deja entrever que Lula habría sido nombrado ministro del gobierno de Rousseff para dificultar que se le detuviera por corrupción (Ibid.).

Las escuchas fueron ordenadas y luego filtradas por el juez Moro, quien en ese momento tenía a su cargo la causa por corrupción y sobornos en la petrolera estatal Petrobras en la que se investigaba al exmandatario. Fue el mismo Juez el que reconoció que filtró los audios (Aranda, 2016), aún a sabiendas de que sólo el Tribunal Supremo estaría autorizado a llevar a cabo una investigación y divulgación de este tipo cuando uno de los investigados tiene prerrogativas por su cargo político.

El caso de las escuchas telefónicas a Uribe, expresidente de Colombia

\section{Las escuchas telefónicas en la legislación colombiana}

El artículo 15 de la Constitución Política de Colombia establece que

La correspondencia y demás formas de comunicación privada son inviolables. Sólo pueden ser interceptados o registrados mediante orden judicial, en los casos y con las formalidades que establezca la ley. Con el fin de prevenir la comisión de actos terroristas, una ley estatutaria reglamentará la forma y condiciones en que las autoridades que ella señale, con fundamento en serios motivos, puedan interceptar o registrar la correspondencia y demás formas de comunicación privada, sin previa orden judicial, con aviso inmediato a la Procuraduría General de la Nación y control judicial posterior dentro de las treinta y seis (36) horas siguientes (...). Los funcionarios que abusen de las medidas a 
que se refiere este artículo incurrirán en falta gravísima, sin perjuicio de las demás responsabilidades a que hubiere lugar.

La ley 600 del 2000 regulaba la intercepción de comunicaciones. En su artículo 301 disponía que podía ordenarse "con el único objeto de buscar pruebas judiciales (...), que se intercepten mediante grabación magnetofónica las comunicaciones telefónicas, radiotelefónicas y similares que utilicen el espectro electromagnético, que se hagan o reciban y que se agreguen al expediente las grabaciones que tengan interés para los fines del proceso. (...) Por ningún motivo se podrán interceptar las comunicaciones del defensor. El funcionario dispondrá la práctica de las pruebas necesarias para identificar a las personas entre quienes se hubiere realizado la comunicación telefónica llevada al proceso en grabación. Tales grabaciones se trasladarán al expediente, por medio de escrito certificado por el respectivo funcionario".

\section{La interceptación de las conversaciones del expresidente Álvaro Uribe con sus abogados}

Álvaro Uribe Vélez fue elegido presidente de la República de Colombia en 2002 y reelegido en 2006 . Fue senador durante el período 2014-2018. El 20 de julio de 2018 tomó posesión, por segunda vez consecutiva, de su cargo como Senador de la República por el partido político Centro Democrático, esta vez para el período 2018-2022 (EI Espectador, 2018).

El 16 de febrero de 2018, la Sala de Casación Penal de la Corte Suprema ("SCP”) habría ordenado investigar al Sr. Álvaro Uribe Vélez por supuestos hechos de corrupción. Sin embargo, esta Sala no tendría la competencia para investigarlo desde la adopción del Acto Legislativo $\mathrm{N}^{\circ} 1$ según el cual la investigación debería estar a cargo de la Sala Especial de Instrucción de la Sala Penal de la Corte Suprema.

Entre los días 7 de marzo y 9 de abril de 2018, la SCP habría interceptado la línea telefónica de Uribe sin que mediara una orden 
judicial de autoridad competente y dentro del marco de un proceso adelantado sin el conocimiento del expresidente. A raíz de esta medida se habrían registrado comunicaciones entre el ex mandatario y sus abogados (El Espectador, 2020). Debe destacarse que, según la Corte, habría existido una orden para interceptar la línea telefónica del congresista Nilton Córdoba pero que por una "falla judicial", se interfirió el teléfono de Uribe (La Semana, 2020).

Recién cinco meses después de iniciadas las investigaciones, el 24 de julio de 2018, la SCP decidió abrir una investigación formal contra el senador Álvaro Uribe Vélez por los delitos de soborno de testigos en la actuación penal (Código Penal de Colombia, Artículo 444a) y fraude procesal (Código Penal de Colombia, Artículo 453) y vinculó al exmandatario al proceso mediante indagatoria. Solo en ese momento éste habría tomado conocimiento del proceso en su contra.

Las pruebas recabadas mediante las escuchas telefónicas mencionadas (que incluyen las comunicaciones privadas entre Uribe y sus abogados) no habrían sido excluidas del proceso, a pesar de que así lo habría solicitado el expresidente, y habrían sido utilizadas por la Corte como base para ordenar su arresto domiciliario (Miranda, 2018; BBC Mundo, 2020).

Expertos internacionales se han referido a la interceptación de las comunicaciones del expresidente Uribe Vélez con sus abogados advirtiendo que se trata de una "injerencia a la privacidad e intimidad" a la luz de los estándares internacionales por tratarse de comunicaciones entre abogado y cliente que gozan de especial protección y deberían permanecer en la intimidad (Infobae, 2021; Mariño Espinosa, 2021).

$\mathrm{Al}$ igual que en los casos anteriores, algunas de las conversaciones grabadas a raíz de las interceptaciones ordenadas por la SCP fueron filtradas a los medios de comunicación (La Semana 2020). 


\section{La relevancia democrática de los procesos políticamente expuestos y la necesidad de jueces imparciales}

El respeto irrestricto de las garantías judiciales permite un espacio de neutralidad necesaria para la confianza de la ciudadanía en la justicia. Esta es la razón por la que diferentes organismos internacionales de derechos humanos han resaltado que las figuras políticas deben ser juzgadas con todas las garantías del debido proceso legal por jueces competentes, independientes e imparciales.

El 3 de septiembre de 2018, el Relator Especial sobre la independencia de los abogados y magistrados de Naciones Unidas envió una comunicación urgente (Relatoría Especial sobre la Independencia de los Magistrados y Abogados, 2018) a Colombia luego de que se denunciara la presunta falta de imparcialidad de los tribunales encargados de las investigaciones en los procesos judiciales iniciados contra Álvaro Uribe Vélez y Álvaro Hernán Prada Artunduaga. Según la comunicación, en relación al ex presidente Uribe Vélez, se habrían vulnerado sus derechos (a) al debido proceso, pues su caso habría sido conocido por juez no competente; (b) a la igualdad, porque en el proceso penal se le habría negado el acceso al expediente y, en consecuencia, a interrogar testigos de cargo; (c) a la garantía de imparcialidad y el principio de igualdad ante los tribunales; (d) a acceder a la doble instancia.

El Relator Especial sostuvo que el tribunal que intervino en el procedimiento - la Sala de Casación Penal de la Corte Suprema de Justicia - habría manifestado con anterioridad una posición desfavorable en contra del Sr. Uribe Vélez.

Una situación similar ocurrió en 2019 con Argentina. El 1 de noviembre de ese año, el Relator Especial sobre la independencia de los magistrados y abogados de Naciones Unidas, Diego García Sayán, analizó posibles actos de intimidación y presión sobre diversos órganos del Poder Judicial de la Nación como el Ministerio Público y el Consejo de la Magistratura por parte del Poder Ejecutivo. 
Adicionalmente, el 9 de octubre de 2020, el Relator Especial de Naciones Unidas para la Independencia de Jueces y Abogados solicitó informes (Relatoría Especial sobre la Independencia de los Magistrados y Abogados, 2020) a Brasil por presuntos actos de intimidación y acoso judicial contra los abogados del expresidente, Lula da Silva. Los ataques habrían consistido en órdenes de búsqueda y decomiso, congelamiento de cuentas bancarias, allanamientos a sus oficinas y cargos criminales.

Más aún, el Relator Especial señaló que la imparcialidad es esencial para el buen funcionamiento de la justicia y que "[l] os jueces no deben colocarse en situaciones en las que su independencia o imparcialidad puedan ser cuestionadas. Para mantener la confianza del público en el sistema judicial es necesario que los jueces eviten cualquier actividad política que pueda comprometer su independencia o arriesgar su imparcialidad" (Ibid.). Para concluir, el Relator expresó lo siguiente:

La imparcialidad es la cualidad fundamental que se exige a un juez y el atributo central del poder judicial. La imparcialidad debe existir tanto como una cuestión de hecho como de percepción razonable. Si se percibe razonablemente la parcialidad, es probable que esa percepción de injusticia destruya la confianza en el sistema judicial. La percepción de imparcialidad se mide según el criterio de un observador razonable. La percepción de que un juez no es imparcial puede surgir de varias maneras, por ejemplo, a través de un conflicto de intereses percibido, el comportamiento del juez en el estrado, o sus asociaciones y actividades fuera del tribunal. Si un juez parece ser parcial, la confianza del público en el poder judicial se ve erosionada. Por lo tanto, un juez debe evitar toda actividad que sugiera que la decisión del juez pueda estar influenciada por factores externos, como la relación personal del juez con una parte o el interés en el resultado de un caso. Al decidir si hay una razón legítima para temer que un juez particular en un caso penal carece de imparcialidad, el punto de vista del acusado es importante 
pero no decisivo. Lo que es decisivo es si ese miedo puede considerarse objetivamente justificado ante el observador razonable que representa a la sociedad (Ibid.) (traducción propia).

\section{Conclusiones}

En este artículo se han descrito seis aspectos que toman relevancia en los procesos políticamente expuestos. De no ser escrupulosamente respetados, pueden impactar seriamente en la validez de los procesos concretos y en la credibilidad del sistema entero. Pueden ordenarse de la siguiente manera:

1. Se requiere imparcialidad del tribunal. Que no haya siquiera apariencia de parcialidad.

2. El juez que interviene debe ser el natural, no una comisión especial designada luego del hecho.

3. Vinculado con lo anterior, el tribunal debe ser competente.

4. La etapa de investigación debe respetar la publicidad del proceso, y por ello debe eliminarse -o minimizarse- el secreto de sumario. De lo contrario, el principio de igualdad se ve afectado.

5. Las intercepciones telefónicas no pueden vulnerar el derecho a la intimidad. Menos aún deben ser filtradas.

6. Se debe asegurar la confidencialidad en la relación entre los abogados y el cliente.

Cuando se ve dañado alguno de estos caracteres, cabe seriamente sospechar sobre la validez del proceso. Posiblemente, existe una búsqueda de fines distintos a los previstos por la Constitución al atribuir competencia a los tribunales para investigar y resolver. 
Las democracias polarizadas requieren que los tribunales sean un espacio ajeno a la disputa partidaria, en el que las decisiones se tomen por evidencia y no por gustos políticos. Cuando el Poder Judicial se convierte en un campo de batalla, el sistema se resiente, pues los jueces pierden la completa independencia que requieren (Hamilton, 1898, 425).

Puede decirse que la democracia funciona con aspectos intocables - los derechos - y aspectos mutables - las políticas - que son parte de la disputa agonal entre los distintos partidos. Pero la contienda necesita ciertos lugares en los que la presión no funciona, o no debería funcionar. Es allí donde se deben ubicar las Cortes.

Los sistemas internacionales de protección de derechos humanos han sido claros a la hora de resaltar la necesidad de tribunales imparciales hasta en su apariencia. Recientemente, la filtración de intercepciones y diálogos de figuras políticas $-\mathrm{y}$ en particular cuando tratan cuestiones con sus abogados- se ha convertido en una forma de conseguir objetivos políticos. Pero trae diversos inconvenientes. La actuación política de ciertos tribunales está a la orden del día. El problema es serio, pues "[s]i se percibe razonablemente la parcialidad, es probable que esa percepción de injusticia destruya la confianza en el sistema judicial”99 (Hamilton, 1898, 425).

${ }^{99}$ La traducción es propia. 


\section{Bibliografía}

Alvarado Velloso, Adolfo. 2003. Introducción al derecho procesal, Tomo I. Buenos Aires, Argentina: Ribinzon-Culzoni.

Amnistía Internacional. 1998. Juicios Justos. Madrid, España: Editorial Amnistía Internacional (EDAI).

Amnistía Internacional. 2014. Juicios Justos. 2nd ed. Madrid, España. Editorial Amnistía Internacional (EDAI).

Aranda, Germán. 2016. "El juez que divulgó las escuchas de Lula y Dilma pide disculpas al Supremo." El Mundo, marzo 30, 2016. https://www.elmundo.es/internacional/2016/03/30/56fb4a552 68e3e6dle8b4639.html.

Asamblea General de Naciones Unidas. 1948. "Declaración Universal de los Derechos Humanos," 217 [III] A. Paris.

Asamblea General de Naciones Unidas. 1990. "Principios Básicos relativos a la independencia de la Judicatura." https://www.ohchr.org/sp/professionalinterest/pages/indepen dencejudiciary.aspx.

BBC Mundo. 2020. "Álvaro Uribe: Corte Suprema de Colombia ordena el arresto domiciliario del expresidente por "riesgos de obstrucción a la justicia." agosto 4, 2020. https://www.bbc.com/mundo/noticias-america-latina53604677.

Boulin Victoria, Ignacio A. 2016. "Back to Politics: Lessons from the Crisis of the Inter-American Commission on Human Rights." Buffalo Human Rights Law Review 22:21-66. https://digitalcommons.law.buffalo.edu/bhrlr/vol22/iss1/2.

Cafferata Nores, José I. 2011. Proceso penal y derechos humanos. La influencia de la normativa supranacional sobre derechos humanos de nivel constitucional en el proceso penal argentino. 2nd ed. Ciudad Autónoma de Buenos Aires: Editores del Puerto.

Caro Coria, Dino C. 2006. "Las garantías constitucionales del proceso penal." Anuario de Derecho Constitucional Latinoamericano, Anuario 2006 Tomo II, 1027-1045. https://revistascolaboracion.juridicas.unam.mx/index.php/anuario-derechoconstitucional/article/view/30342/27388. 
CIDH. 1999. “Tercer Informe sobre la Situación de los Derechos Humanos en Colombia," OEA/Ser.L/V/II.102, Doc. 9 rev. 1, Capítulo V.

CIDH. 2002. "Informe sobre Terrorismo y Derechos Humanos," OEA/Ser.L/V/ll.116, Doc. 5 rev. 1 corr.

Comité de Derechos Humanos. 1984. “Observación General Nro 13 Administración de justicia (artículo 14)."

Comité de Derechos Humanos. 2007. "Observación General Nro. 32. Artículo 14. El derecho a un juicio imparcial y a la igualdad ante los tribunales y cortes de justicia”. https://undocs.org/es/CCPR/C/GC/32.

“Concepto de imparcialidad.” Real Academia Española. Consultado el 30 de abril de 2021. https:/ / dle.rae.es/imparcialidad.

Consejo de Derechos Humanos. 2013. Resolución A/HRC/23/6, La independencia e imparcialidad del poder judicial, los jurados y asesores y la independencia de los abogados. https://www.acnur.org/fileadmin/Documentos/BDL/2014/968 3.pdf.

Consejo de Europa. 1950. Convenio Europeo para la Protección de los Derechos Humanos y de las Libertades Fundamentales, Entrada en vigor: 3 de septiembre de 1953. Roma.

Dawson Jr., Thomas C., John T. Tucker III, and Kevin J. Whyte. 1985. "The Attorney-Client Privilege." Law review, 19 U. Rich. L. Rev. 559

19:559-600. https://scholarship.richmond.edu/lawreview/vol19/iss3/9.

El audio de Cristina Kirchner a Parrilli. 2021. YouTube. https://www.youtube.com/watch?v=Mi2DrAY0-X4.

El Espectador. 2018. “Álvaro Uribe obtuvo la votación más alta del Senado.” marzo 12, 2018. https://www.elespectador.com/elecciones2018/noticias/politica/alvaro-uribe-obtuvo-la-votacion-masalta-del-senado-articulo-743877.

El Espectador. 2020. "Los temas de las conversaciones entre el senador Uribe y Diego Cadena, según la Corte Suprema." agosto 10, 2020. https://www.elespectador.com/noticias/judicial/lasinterceptaciones-de-la-corte-suprema-al-senador-uribe-y-suabogado-diego-cadena. 
El País. 2021. “Argentina: 8 de cada 10 no confía en la Justicia.” febrero 17, 2021. https://www.elpais.com.uy/mundo/argentina-confiajusticia.html.

El Perfil. 2019. "Sobreseyeron a Oscar Parrilli en la causa por presunto encubrimiento a Perez Corradi." mayo 8, 2019. https://www.perfil.com/noticias/politica/sobreseyeron-oscarparrilli-por-presunto-encubrimiento-narco-ibar-perezcorradi.phtml.

El Tiempo. 1997. "Arranca desmonte de justicia sin rostro." septiembre 3 , 1997. https://www.eltiempo.com/archivo/documento/MAM-699119.

El Tiempo. 2018. "La justicia volvió a filtrar conversaciones privadas de CFK con Parrilli." febrero 19, 2018. https://www.tiempoar.com.ar/nota/la-justicia-volvio-a-filtrarconversaciones-privadas-de-cfk-con-parrilli.

Estella de Noriega, Antonio. 2020. "Confianza institucional en América Latina: un análisis comparado." Fundación Carolina Documentos de trabajo nro. 34, no. 2da época (abril): 10. https://doi.org/10.33960/issn-e.1885-9119.DT34.

Faulkner, David, and Ros Burnett. 2012. "Where Next for Criminal Justice?” The Policy Press, Bristol.

Ferrajoli, Luigi. 2005. Derecho y razón. Teoría del garantismo penal. 7th ed. Madrid: Trotta.

Fundación para el Debido Proceso Legal. 2007. "Controles y descontroles de la corrupción judicial. Evaluación de la corrupción judicial y de los mecanismos para combatirla en Centroamérica y Panamá.” Estados Unidos de América, Washington DC. https://www.corteidh.or.cr/tablas/24329.pdf.

Giraudeau, Géraldine. 2016. “The Principles of Confidentiality and Noninterference in Communications with Lawyers and Legal Advisers in Recent ICJ and ECHR Case Law." ASIL Insights 20, no. 16 (octubre). https://www.asil.org/insights/volume/20/issue/16/principlesconfidentiality-and-noninterference-communications-lawyers.

Gómez, Lucas. 2021. “Cuando la justicia se politiza cruje el Estado de Derecho." Infobae, marzo 18, 2021. https://www.infobae.com/america/opinion/2021/03/18/cuand o-la-justicia-se-politiza-cruje-el-estado-de-derecho/. 
Hamilton, Alexander. 1898. The Federalist Papers. New York, Scott, E. H. ed.

Infobae. 2017. "Denunciaron a Cristina Kirchner por armar causas judiciales", $\quad$ enero 2017. https://www.infobae.com/politica/2017/01/20/denunciaron-acristina-kirchner-por-la-escucha-en-la-que-pregunta-por-lascausas-q ue-le-armaron-a-stiuso/.

Infobae. 2021. "Juristas internacionales emitieron conceptos a la Fiscalía sobre caso Álvaro Uribe Vélez." marzo 15, 2021. https://www.infobae.com/america/colombia/2021/03/15/jurist as-internacionales-emitieron-conceptos-a-la-fiscalia-sobrecaso-alvaro-uribe-velez/.

Isola, Alfredo Eduardo. 2006. "El juez: su imparcialidad frente a los temas ambientales," Id SAIJ: DACF050108. www.saij.jus.gov.ar.

La Prensa. 2007. "Justicia no haya delitos en juicios contra Callejas." enero 31, 2007. https://www.laprensa.hn/honduras/69019897/justicia-no-halla-delitos-en-juicios-contra-callejas.

La Semana. 2020. “"Álvaro Uribe, buenos días": el audio de la primera interceptación de la Corte." agosto 9, 2020. https://www.semana.com/nacion/articulo/alvaro-uribebuenos-dias-el-audio-de-la-primera-interceptacion-de-lacorte $/ 692967 /$.

Lissardy, Gerardo. 2016. "La grabación de una conversación entre Dilma Rousseff y Lula da Silva que agrava la crisis política en Brasil." BBC Mundo (Brasil), marzo 17, 2016. https://www.bbc.com/mundo/noticias/2016/03/160316_escuc ha_telefonica_dilma_lula_brasil_ps.

Loianno, Adelina. 2020. "Independencia e imparcialidad judicial. TEDH, Affaire Boyan Gospodinov c. Bulgarie, 5 de abril de 2018 y Case of Otegi Mondragon y otros v. España, 6 de noviembre de 2018." Revista Debates sobre Derechos Humanos, no. 3 (abril), $213 \quad$ - 224. https://publicaciones.unpaz.edu.ar/OJS/index.php/debatesdd $\mathrm{hh} /$ article/view/648.

López Girondo, Alberto. 2019. "Abogados denuncian espionaje a llamadas de Lula y sus abogados.” El Tiempo, junio 9, 2019. https://www.tiempoar.com.ar/nota/abogados-denuncianespionaje-a-llamadas-de-lula-y-sus-abogados. 
Maier, Julio B. 2004. Derecho Procesal Penal, Tomo I (Fundamentos). 2nd ed. Buenos Aires: Editores del Puerto.

Mariño Espinosa, Lilian. 2021. "Herdegen señaló “injerencias muy graves" en proceso de Álvaro Uribe por interceptaciones." Asuntos Legales, abril 2021. https://www.asuntoslegales.com.co/actualidad/herdegensenalo-injerencias-muy-graves-en-proceso-uribe-porinterceptaciones-3150987.

Miranda, Boris. 2018. "Los polémicos elementos con los que la Corte Suprema de Colombia decidió procesar al expresidente Álvaro Uribe." $B B C \quad$ Mundo, julio 26, 2018. https://www.bbc.com/mundo/noticias-america-latina44971952.

Montero Aroca, Juan. 2006. "Derecho a la imparcialidad judicial, Comentario al artículo II-107 del Tratado por el que se establece una Constitución para Europa y el artículo 6.1 del Convenio Europeo de Derechos Humanos". Revista Europea de Derechos Fundamentales 7:páginas 69 a 111.

Naciones Unidas. 1990. "Principios Básicos sobre la Función de los Abogados", Adoptados por el Octavo Congreso de las Naciones Unidas sobre Prevención del Delito y Tratamiento del Delincuente, La Habana, 27 de agosto a 7 de septiembre de 1990.

Naciones Unidas, Consejo Económico y Social. 1985. "La administración de justicia y los derechos humanos de los detenidos : estudio sobre la independencia e imparcialidad de los jueces, jurados y asesores y la independencia de los abogados : informe final del Relator Especial L.M. Singhvy", E/CN.4/Sub. 2/1985/18/Add. Geneva.

Naciones Unidas, Relatoría Especial para la Independencia de Magistrados y Abogados. 2009. "Informe anual", A/64/181.

Notiamerica. 2016. "Lula pide investigar al juez del caso Petrobras por las escuchas telefónicas". abril 7, 2016. https://www.notimerica.com/politica/noticia-brasil-lula-pideinvestigar-juez-caso-petrobras-escuchas-telefonicas20160407193515.html.

Offe, Claus. 2011. "Crisis and Innovation of Liberal Democracy: Can Deliberation Be Institutionalised?" Czech Sociological Review 47 
(3):

http://www.euro.centre.org/data/1310545115_27711.pdf.

Offe, Claus. 2011. "Crisis and Innovation of Liberal Democracy: Can Deliberation Be Institutionalised?" Czech Sociological Review 47 (3): 447 http://www.euro.centre.org/data/1310545115_27711.pdf.

472.

Página 12. 2017. “Es una operación política completa.” enero 25, 2017. https://www.pagina12.com.ar/16060-es-una-operacionpolitica-completa.

Pegoraro, Mara. 2018. "Imparcialidad y desconfianza: tensiones del Poder Judicial." El Estadista (Buenos Aires), agosto 30, 2018. https://elestadista.com.ar/?p=14954.

Política Argentina. 2017. "Espionaje: las escuchas a Parrilli que llegaron a los medios tenían orden judicial para ser destruidas". febrero 16 , 2017. https://www.politicargentina.com/notas/201702/19435espionaje-las-escuchas-a-parrilli-que-llegaron-a-los-mediostenian-orden-judicial-para-ser-destruidas.html.

Sharman, Jeffrey M. 1996. Ética judicial: independencia, imparcialidad e integridad. Washington D.C.: Banco Interamericano de Desarrollo, Departamento de Desarrollo Sostenible División de Estado, Gobernabilidad y Sociedad Civil. https://biblioteca.cejamericas.org/bitstream/handle/2015/3912 /bid-etica-judicial.pdf.

Télam. 2017. "El juez Lijo aseguró que la defensa de Parrilli conocía el contenido de las escuchas”. enero 25, 2017. https://www.telam.com.ar/notas/201701/177723-lijo-escuchasparrilli-cristina-kirchner.html.

Tyler, Tom R. 2009. "Legitimacy and Criminal Justice: The Benefits of Self-Regulation", Ohio State Journal of Criminal Law 7, no. 1 (abril): 307-359.

Jurisprudencia y decisiones de organismos internacionales

CIDH. 2017. "Informe de Fondo No. 72/17. Caso 13.019 Eduardo Rico respecto de Argentina," OEA/Ser.L/V/II.163, Doc. 86, 5. 
Comité de Derechos Humanos. 1993. "Caso Angel N. Oló Bahamonde v. Equatorial Guinea," Comunicación No. 468/1991, U.N. Doc. CCPR/C/49/D/468/1991.

Comité de Derechos Humanos. 2000. “Comunicación N 907/2000," $\mathrm{CCPR} / \mathrm{C} / 85 / \mathrm{D} / 907 / 2000$.

Comité de Derechos Humanos. 2002. “Comunicación N 1117/2002,” CCPR/C/81/D/1117/2002.

Comité de Derechos Humanos. 2007. "Adenda en el Reporte del Grupo de Trabajo sobre Detención Arbitraria, Misión a Turquía," A/HRC/4/40/Add.5.

Corte de Justicia de la Unión Europea. 2007. “Akzo Nobel Chemicals Ltd y Akcros Chemicals Ltd contra Comisión de las Comunidades Europeas," Asuntos acumulados T-125/03 y T-253/03, Sentencia del 17 de septiembre de 2007.

Corte Europea de Derechos Humanos. 1984. “Caso Malone vs. Reino Unido". Sentencia del 2 de agosto de 1984. Serie A 82.

Corte Europea de Derechos Humanos. 1984. "Caso Sramek vs. Austria," Sentencia del 22 de octubre de 1984, Serie A 84.

Corte Europea de Derechos Humanos. 1984. "Caso Piersack vs. Belgium," Sentencia de 26 de octubre de 1984, Serie A 85.

Corte Europea de Derechos Humanos. 1996. "Caso Thomann contra Suiza," Sentencia de 10 de junio de 1996, Repertorio de sentencias y resoluciones 1996-III.

Corte Europea de Derechos Humanos. 1996. "Caso Thomann contra Suiza," Sentencia de 10 de junio de 1996, Repertorio de sentencias y resoluciones 1996-III.

Corte Europea de Derechos Humanos. 1997. “Caso Harfold vs. Reino Unido", Sentencia de 25 de junio de 1997, Repertorio de sentencias y resoluciones, 1997-III.

Corte Europea de Derechos Humanos. 1998. "Caso Kopp v. Suiza”, Sentencia del 25 de marzo de 1998, Repertorio de sentencias y resoluciones, 1998-II.

Corte Europea de Derechos Humanos. 1998. "Valenzuela Contreras c. España, Sentencia de 30 de julio de 1998, Repertorio de sentencias y resoluciones, 1998-V. 
Corte Europea de Derechos Humanos. 2007. "Caso Copland vs. Reino Unido", Sentencia del 3 de septiembre de 2007, Repertorio de sentencias y resoluciones, 2007-I.

Corte Europea de Derechos Humanos. 2009. Caso Micallef Joseph v. Malta, Sentencia del 15 de octubre de 2009, Repertorio de sentencias y resoluciones, 1999.

Corte Europea de Derechos Humanos. 2009. "Caso Olújic v. Croatia," Sentencia del 5 de febrero de 2009, (Sect.1) Aplicación no. $22330 / 05$.

Corte Europea de Derechos Humanos. 2012. "Caso Harabim v. Slovakya," Sentencia del 20 de noviembre de 2012, Aplicación no. 58688/11.

Corte Europea de Derechos Humanos.. 2012. "Caso Michaud v. Francia", Sentencia del 6 de diciembre de 2012, Repertorio de sentencias y resoluciones, 2012.

Corte Europea de Derechos Humanos. 2016. "Versini-Campinchi y Crasnianski v. Francia”, Sentencia del 16 de junio de 2016.

Corte IDH. 1987. “Opinión Consultiva OC-9/87 “Garantías Judiciales en estados de emergencia (ARTS. 27.2, 25 y 8 Convención Americana sobre Derechos Humanos)", 6 de octubre de 1987, Serie A No. 9.

Corte IDH. 1997. “Caso Suárez Rosero v. Ecuador,” Sentencia de 12 de noviembre de 1977 (Fondo), Serie C No. 35.

Corte IDH. 1999. "Caso Castillo Petruzzi y otros vs. Perú," Fondo, Reparaciones y Costas, Sentencia de 30 de mayo de 1999, Serie C No. 52.

Corte IDH. 2000. “Caso Cantoral Benavides Vs. Perú,” Sentencia de 18 de agosto de 2000 (Fondo), Serie C No. 69.

Corte IDH. 2001. "Caso del Tribunal Constitucional vs. Perú," Sentencia del 31 de enero de 2001 (Fondo, reparaciones y costas), Serie C No. 71.

Corte IDH. 2001. “Caso Baena Ricardo y otros vs. Panamá,” Sentencia de 2 de febrero de 2001 (Fondo, Reparaciones y Costas), Serie C No. 72 . 
Corte IDH. 2001. "Caso Ivcher Bronstein Vs. Perú," Sentencia de 6 de febrero de 2001 (Reparaciones y Costas), Serie C No. 74.

Corte IDH. 2001. “Caso Las Palmeras Vs. Colombia,” Sentencia de 6 de diciembre de 2001 (Fondo), Serie C No. 96.

Corte IDH. 2003. "Caso Bulacio vs. Argentina," Sentencia de 18 de septiembre de 2003, Serie C No. 100.

Corte IDH. 2003. "Caso Juan Humberto Sánchez Vs. Honduras," Sentencia de 7 de junio de 2003, Serie C No. 99.

Corte IDH. 2004. "Caso De La Cruz Flores vs. Perú," Fondo, Reparaciones y Costas, Sentencia de 18 de noviembre de 2004, Serie C No. 115.

Corte IDH. 2004. "Caso Herrera Ulloa vs. Costa Rica," Excepciones Preliminares, Fondo, Reparaciones y Costas, Sentencia de 2 de julio de 2004. Serie C No. 107.

Corte IDH. 2005. "Caso Yatama Vs. Nicaragua," Excepciones Preliminares, Fondo, Reparaciones y Costas, Sentencia de 23 de junio de 2005, Serie C No. 127.

Corte IDH. 2005. “Caso Palamara Iribarne Vs. Chile,” Sentencia de 22 de noviembre de 2005. Serie C No. 135.

Corte IDH. 2006. “Caso López Álvarez vs. Honduras,” Sentencia del 1 de febrero de 2006 (Fondo, reparaciones y costas), Serie C No. 141.

Corte IDH. 2008. "Caso Yvon Neptune Vs. Haití," Sentencia del 6 de mayo de 2008, (Fondo, Reparaciones y Costas), serie C Nro. 180.

Corte IDH. 2008. "Caso Apitz Barbera y otros ("Corte Primera de lo Contencioso Administrativo") vs. Venezuela," Sentencia del 5 de agosto de 2008, Serie C No. 182.

Corte IDH. 2009. “Caso Tristán Donoso vs. Panamá,” Excepción preliminar, Fondo, Reparaciones y Costas, Sentencia del 27 de enero de 2009, Serie C No 193.

Corte IDH. 2009. "Caso Escher y Otros vs. Brasil," Sentencia de 6 de julio de 2009. Serie C, No. 200.

Corte IDH. 2009. “Caso Barreto Leiva vs. Venezuela,” Sentencia del 17 de noviembre de 2009, Serie C, No. 206. 
Corte IDH. 2014. "Caso Norin Catriman y otros vs. Chile," Sentencia de 29 de mayo de 2014, Serie C, No. 279.

Corte IDH. 2015. “Caso López Lone y otros Vs. Honduras,” Excepción Preliminar, Fondo, Reparaciones y Costas, Sentencia de 5 de octubre de 2015, Serie C No. 302.

Corte Internacional de Justicia. 2014. "Questions Relating to the Seizure and Detention of Certain Documents and Data (Timor-Leste v. Australia)," Provisional Measures, Order of 3 March 2014, I.C.J. Reports 2014.

Corte Suprema de Justicia de Colombia. 2021. "Corte Suprema ordena detención domiciliaria del senador Álvaro Uribe,” fecha 4 de agosto de 2021. https://cortesuprema.gov.co/corte/index.php/2020/08/04/cort e-suprema-ordena-detencion-domiciliaria-del-senador-alvarouribe/.

Corte Suprema de Justicia de Colombia, Sala Especial de Instrucción. 2020. Magistrado Ponente César Augusto Reyes Medina, decisión del 3 de agosto de 2020, radicación No. 52.240. https://www.eltiempo.com/uploads/files/2020/08/08/decision -de-la-corte.pdf.

Court of the Kings Bench, $R v$ Chancellor of the University of Cambridge (Dr Bentley's Case), 1 Str 557 at 567 [93 ER 698 at 704]. 1723.

Naciones Unidas, Relatoría Especial sobre la Independencia de los Magistrados y Abogados. 2018. "Comunicación enviada el Estado de Colombia”, COL 5/2018. Geneva, Switzerland. https://spcommreports.ohchr.org/TMResultsBase/DownLoadP ublicCommunicationFile?gId=24043.

Naciones Unidas, Relatoría Especial sobre la Independencia de los Magistrados y Abogados. 2020. "Comunicación enviada al Estado de Brasil”, AL BRA 11/2020. Geneva, Switzerland. https://spcommreports.ohchr.org/TMResultsBase/DownLoadP ublicCommunicationFile?gId=25637.

Superior Tribunal de Justicia. 2021. “Ag. Reg. No habeas corpus 193.726 Paraná", Voto del Relator Min. Edson Fachin. http://www.stf.jus.br/arquivo/cms/noticiaNoticiaStf/anexo/H C193726AgReAgRnoAgRVotoMGM.pdf. 
Suprema Corte de Justicia de Virginia, Estados Unidos. 1871. "Caso Chahoon v. Commonwealth”, 62 Va. (21 Gratt.) 838.

Supremo Tribunal Federal. 2021. “Ag. Reg. No Habeas Corpus 193.726 Paraná”, Resolución que confirmó la decisión del Segundo Panel del Tribunal Supremo Federal, votos de los ministros Gilmar Mendes, Nunes Marques, Alexandre de Moraes, Dias Toffoli y Ricardo Lewandowski, y los ministros Rosa Weber y Cármen Lúcia. Portal del Supremo Tribunal Federal. http://portal.stf.jus.br/noticias/verNoticiaDetalhe.asp?idConte $\mathrm{udo}=464602 \&$ ori $=1$.

\section{Legislación}

Acto Legislativo No. 1, por medio del cual se modifican los artículos 186, 234 y 235 de la Constitución Política y se implementa el derecho a la doble instancia y a impugnar la primera sentencia condenatoria. 2018.

Constitución de la República Federativa del Brasil. 1988.

Constitución Política de Colombia. 1991.

Código de Procedimiento Penal de Colombia, Ley Nro. 600, 24 de julio. 2000.

Código Penal de Colombia, Ley 599, 24 de julio. 2000.

Código Procesal Penal de la Nación Argentina, Ley $\mathrm{N}^{\circ} 27.063,4$ de diciembre. 2014. http://servicios.infoleg.gob.ar/infolegInternet/verNorma.do?id $=239340$.

Decreto de Necesidad y Urgencia Nro. 256/2015 del Poder Ejecutivo Nacional "Transfierase el Departamento de Interceptación y Captación de las Comunicaciones”. 24 de diciembre de 2015.

Ley de Inteligencia Nacional N. 25.520, Bases jurídicas, orgánicas y funcionales del Sistema de Inteligencia de la Nación. Principios generales. Protección de los derechos y garantías de los habitantes. Organismos de Inteligencia. Política de Inteligencia. Sancionada el 27 de noviembre 27 de 2001 y promulgada el 3 de diciembre de 2001. http://servicios.infoleg.gob.ar/infolegInternet/anexos/7000074999/70496/norma.htm. 
Ley de Interceptación Telefónica de Brasil, Nro. 9.296/96. 1996.

Ley de las Organizaciones Criminales de Brasil, Nro. 12.850/13. 2013.

Ley Nacional de Telecomunicaciones $\mathrm{N}^{\circ}$ 19.798, Buenos Aires. Sancionada el 22 de agosto de 1972. http://servicios.infoleg.gob.ar/infolegInternet/anexos/3000034999/31922/texact.htm. 